For submission to Journal of Contaminant Hydrology:

\title{
Calibration of Yucca Mountain Unsaturated Zone Flow and Transport Model using Porewater Chloride Data
}

\author{
Jianchun Liu, Eric L. Sonnenthal, and Gudmundur S. Bodvarsson \\ Earth Sciences Division \\ Lawrence Berkeley National Laboratory \\ Berkeley, CA 94720, USA
}

\begin{abstract}
In this study, porewater chloride data from Yucca Mountain, Nevada, are analyzed and modeled by 3-D chemical transport simulations and analytical methods. The simulation modeling approach is based on a continuum formulation of coupled multiphase fluid flow and tracer transport processes through fractured porous rock, using a dual-continuum concept. Infiltration-rate calibrations were using the pore water chloride data. Model results of chloride distributions were improved in matching the observed data with the calibrated infiltration rates. Statistical analyses of the frequency distribution for overall percolation fluxes and chloride concentration in the unsaturated zone system demonstrate that the use of the calibrated infiltration rates had insignificant effect on the distribution of simulated percolation fluxes but significantly changed the predicated distribution of simulated chloride concentrations. An analytical method was also applied to model transient chloride transport. The method was verified by 3-D simulation results as able to capture major chemical transient behavior and trends. Effects of lateral flow in the Paintbrush nonwelded unit on percolation fluxes and chloride distribution were studied by 3-D simulations with increased horizontal permeability. The combined results from these model calibrations furnish important information for the UZ model studies, contributing to performance assessment of the potential repository.
\end{abstract}

Keywords: Chloride, Unsaturated zone, Yucca Mountain, Geochemistry, Infiltration map, Percolation. 


\section{Introduction}

Yucca Mountain, Nevada, is a potential site for the U.S. Department of Energy highlevel nuclear waste repository. The map of the region is given in Fig. 1, showing the surface projections of the potential repository, the ECRB (Enhanced Characterization of the Repository Block) tunnel, the ESF (Exploratory Studies Facility) tunnel, the locations of deep boreholes and some major faults, and the outline of the Lawrence Berkeley National Laboratory 3-D site-scale model (Hinds and Pan, 2000; Wu et al., 2000). The domain of the unsaturated zone (UZ) model system covers a total area of approximately $40 \mathrm{~km}^{2}$ of Yucca Mountain and, depending on the local topography, the thickness varies from 500 to $700 \mathrm{~m}$, overlying a relatively flat water table in the vicinity of the potential repository area. The potential repository would be located in the highly fractured Topopah Spring welded unit, more than $200 \mathrm{~m}$ above the water table, with an approximate area of $1000 \mathrm{~m}$ by $5,000 \mathrm{~m}$. The UZ system of the mountain has been the subject of intensive geological, hydrologic, and subsurface engineering studies. UZ models are representations of water movement affected by climate, and by hydrologic properties of porous and fractured rock, welded and nonwelded tuff, and fault-bounded tuff layers above the water table. A dry climate and a deep water table characterize the ambient conditions at Yucca Mountain. Understanding of unsaturated flow at Yucca Mountain has evolved from decades of site characterization and model calibration (Flint et al., 2001). Modeling a realistic flow field and quantifying its uncertainties improves our understanding of potential repository performance.

The main issues in the model studies are the flow and transport pathways through the system, particularly the percolation flux at the repository and possible seepage into the drifts, flow paths below the repository, and radionuclide retardation and transport times to the saturated zone. Long-term performance of the potential repository is dependent on the rate of subsurface fluid percolation. Percolation flux strongly depends on the infiltration rate and its spatial and temporal distribution. Net infiltration is the fraction of precipitation (including snowmelt and surface water run-on) that penetrates the ground surface to a depth where the liquid water can no longer be removed by evaporation or transpiration by plants. Estimates of net infiltration are based on the precipitation rate and 
temperature predicted for present and future climates. The net-infiltration distributions are used as direct inputs at the upper boundary of the UZ Flow and Transport Model. Relatively high net infiltration rates occur generally in the northern portion of the site at high elevations and along the ridge where fractured bedrock is exposed. The infiltration model based on the evapotranspiration approach (Hevesi et al., 1992; Flint and Flint, 1994; Flint et al., 1996) indicates that the present mean infiltration could vary from less than one millimeter per year to as high as several tens of millimeters per year (Geomatrix Consultants, 1997). Uncertainties in estimating infiltration also include the possible effects of climate change. Variations in climate over the past 100,000 years or so have been used to estimate the possible range in infiltration rate over the next 10,000 years (Sonnenthal and Bodvarsson, 1999). Precipitation and temperature records of present-day meteorological stations at colder and wetter sites are selected to represent future climate states. Each of the future climate states is treated as a sequence of three climate states: modern, monsoon, and glacial transition and is associated with analog sites that represent upper-bound, mean, and lower-bound precipitation scenarios.

Lateral flow diversion is another factor affecting the percolation flux at the repository. The UZ flow model consists of a series of welded and nonwelded volcanic tuff layers with different hydrogeological characteristics and fracture densities bisected by faults. Welded units are generally heavily fractured, with fracture flow considered to be the dominant mode of air and water movement. Nonwelded units, however, have higher porosity and fewer fractures, and matrix flow is believed to be predominant. An east-west cross-section through Yucca Mountain showing the major hydrogeological units is schematically depicted in Fig. 2 (Clayton, 2000). From shallow to deep, there are the Tiva Canyon welded unit (TCw), Paintbrush nonwelded unit (PTn), Topopah Spring welded unit (TSw), and Calico Hills nonwelded unit (CHn). Below the $\mathrm{CHn}$, the units just above and intersecting the water table are the Prow Pass (PPn) and Bullfrog tuffs (BF). The TSw unit hosts the north-south drift of the ESF. According to the current conceptual model, net infiltration through the fractured $\mathrm{TCW}$ is dominated by significant fracture flow before entering the PTn. A transition from fracture-dominated flow to matrix-dominated flow occurs when fluids flow from TCw into PTn. PTn layers have 
variable porosity and permeability with an average of about $40 \%$ and $300 \mathrm{md}$, respectively (Flint, 1998). With its characteristics of high matrix porosity, low fracture frequency, and the existence of tilted layers of nonwelded vitric and bedded tuff units, the PTn may effectively damp out episodic infiltration pulses and divert percolating water to the intercepting faults and fault zones. Pneumatic data from sampling points above, within, and below the PTn are used to calibrate the effective vertical permeability through the PTn, whereas saturation, water-potential, and fault characteristic data are used to calibrate the unsaturated property parameters. Alternative PTn conceptual models are being developed that try to address uncertainties associated with lateral flow at PTn interfaces and within the PTn, the role of PTn in damping spatial and temporal variabilities, and the sustainability of fast flow paths (fractures and faults) through the units (Ahlers and Liu, 2000; Wu et al., 2000).

Geochemical data provide additional information to analyze the UZ system. Porewater chemical concentration data have been used to calibrate the UZ model to bound the infiltration flux, flow pathways, and transport time (Fabryka-Martin et al., 1994; Johnson and Depaolo, 1994; Meijer, 1995; Flint et al., 1996; Triay et al., 1996; Yang et al., 1996, 1998; Fabryka-Martin et al., 1997; Sonnenthal and Bodvarsson, 1999; Scanlon, 2000). The distribution of chloride in the UZ is useful because this information integrates the effects of a variety of factors, such as hydrological processes of surface precipitation, evapotranspiration, the fracture-matrix interactions of flow and transport, large-scale mixing via lateral transport, and the history of climate changes and recharge. The chloride data, together with other geochemical and age data, may play an important role in determining the percolation distributions. The evaluation of flow and transport processes from the chloride data is an inverse procedure. Measured chloride concentration data are assumed to represent the average in situ porewater chloride concentration at depth. The transport simulation results of chloride subsurface distribution are compared with the measured concentration data to infer the flow and transport parameters, including permeability distribution, the infiltration rate, etc. The infiltration rate is calibrated based on the chloride deposition rate and chloride concentration in precipitation, which is diluted inversely proportional to the increased 
infiltration rate. As in most inverse processes, more than one conceptual model may result in the same chloride distribution. Corroboration from other chemical tracers or physical data is often needed to discriminate between different models and resolve nonunique problems. Natural and anthropogenic environmental tracers provide useful data for evaluating the processes over various time and space scales. By synthesizing geochemical, geologic, and hydrologic data, the model results enhance the understanding of flow and transport processes and the development of hydrologic parameter sets and conceptual models (Sonnenthal and Bodvarsson, 1999; Scanlon, 2000, Wu et al., 2000).

In this study, measured porewater chloride concentration data are analyzed and modeled by 3-D chemical transport simulations and analytical methods. Infiltration-rate calibrations were performed using the porewater chloride data. Model results of chloride distributions were improved in matching the observed data when the calibrated infiltration maps were used. Statistical analyses concerning the frequency distribution of percolation fluxes and chloride concentrations in the system were conducted, and the results demonstrate that the impact of infiltration changes on the percolation fluxes are not significant compared to that on the chloride concentration distributions. In addition, an analytical method was applied to analyze transient chloride transport. The method was verified by 3-D simulation results as able to capture major chemical transient behavior and trends. The transition to matrix flow in PTn is expected to produce a more uniform chloride distribution in the underlying units. Lateral flows in the PTn and their effects on water flux and chloride distribution were studied by 3-D simulations with increased horizontal permeability, with the degree of the effect varying with location. The combined results from these model calibrations furnish important information for the UZ Model studies, contributing to the performance assessment of the potential repository.

\section{Physical properties and chloride model}

\subsection{Porewater chloride data}

Porewater chloride data available and applied to this study were from samples collected in nine boreholes (NRG-6, NRG-7A, SD-6, SD-7, SD-9, SD-12, UZ\#4, UZ-14, 
and UZ\#16), the ECRB tunnel, and the ESF tunnel (including South Ramp, North Ramp, and Main Drift). The detailed description of these data was given in several reports (Yang et al., 1998, Fabryka-Martin et al., 1998). Because of difficulties in extracting porewaters from low porosity welded tuffs, chloride concentrations from the UZ are limited mostly to the nonwelded portion of the Tiva Canyon tuff, the underlying Paintbrush bedded tuffs, the top nonwelded zone of the Topopah Spring hydrogeologic unit, the Calico Hills unit and underlying geologic units. Large differences exist in chloride concentrations in these porewater samples from different locations. Water compositions in the TCW and PTn are characteristic of interaction with near-surface soils (Yang et al., 1996). The borehole concentration measurements in the PTn range from 45 to $245 \mathrm{mg} / \mathrm{L}$ in UZ-14, 47 to $185 \mathrm{mg} / \mathrm{L}$ in NRG-6, 93 to $170 \mathrm{mg} / \mathrm{L}$ in SD-9, 46 to $60 \mathrm{mg} / \mathrm{L}$ in SD-12, and about $77 \mathrm{mg} / \mathrm{L}$ in SD-7. In the North Ramp of the ESF, the data show the trend of higher chloride concentration near the top of the PTn. Analyses of the concentrations in porewaters from the Topopah Spring unit (mostly restricted to the nonwelded top) are of samples from the upper lithophysal horizon of the TSw in the South Ramp of the ESF, which give chloride concentrations ranging from 17 to $150 \mathrm{mg} / \mathrm{L}$ (Fabryka-Martin et al., 1998).

\subsection{Chloride surface fluxes and concentrations in precipitation}

The chloride mass balance approach has been used in many studies to quantify fluxes and ages (Allison and Hughes, 1978). Uncertainties associated with the approach include uncertainties in the chloride input to the system, in transport process, and in chloride output or porewater chloride concentration measurements. The use of porewater chloride concentrations as a method for estimating infiltration rates and as a tracer of flux redistribution with depth is based on the assumption that initial chloride concentrations are inversely proportional to the infiltration rate, i.e., as water is removed from the shallow surface by evaportranspiration, the chloride concentration in the residual water increases. Modeling the chloride distribution requires either its concentration in infiltrating water or its total surface flux pattern (Sonnenthal and Bodvarsson, 1999). The chloride flux includes dissolved material in rain, snow, and a contribution from windblown dust (Meijer, 1995; Fabryka-Martin et al., 1996, 1997; Triay et al., 1996; 
Tyler et al., 1996). The strong vertical and lateral heterogeneity in porewater chloride concentrations indicate that the waters have undergone differing degrees of evaporation, interacted with waters flowing through fractures and the matrix porewaters, and been involved in large-scale mixing via lateral flow. Chloride has lower concentrations in regions of high infiltration below thin soil and higher concentrations beneath thick alluvial deposits, assuming that little surface runoff has taken place. Spatial variations in evapotranspiration must be included in estimating the chloride concentrations in infiltrating water to reflect the large variations in chloride concentrations. Both the chloride fluxes and concentrations must be considered, because areas of higher fluxes may have lower concentrations (owing to increased infiltration), and thus less evaporative concentration. Runoff will result in areas with higher surface water-fluxes and thus higher chloride fluxes. These higher chloride fluxes could lead to high concentrations in infiltrating water if evapotranspiration is high, or low concentrations if little evaporation takes place, resulting in the infiltration of a large volume of dilute water. The precipitation rates were calculated using the spatially varying precipitation data provided at a $30 \mathrm{~m}$ gridblock resolution (Flint et al., 1996). Precipitation and infiltration fluxes were calculated for the 3-D model boundary by averaging all points enclosed in a circular area equivalent to the model grid block surface area. Combining the mean annual precipitation of about $170 \mathrm{~mm} /$ year calculated for Yucca Mountain (Flint et al., 1996) with the present-day chloride deposition rate of $106 \mathrm{mg} / \mathrm{m}^{2} /$ year given by Fabryka-Martin et al. (1996) yields a mean chloride concentration of about $0.62 \mathrm{mg} / \mathrm{L}$ (Fabryka-Martin et al., 1997). Note that the most recent estimate of chloride deposition rate is reported as 60 $\mathrm{mg} / \mathrm{m}^{2} /$ year with an effective concentration of $0.35 \mathrm{mg} / \mathrm{L}$ (Fabryka-Martin et al., 2000), which are $56 \%$ of the values used in this study $\left(107 \mathrm{mg} / \mathrm{m}^{2} /\right.$ year and $\left.0.62 \mathrm{mg} / \mathrm{L}\right)$. There is enough uncertainty in these estimates that the calculations in this study are still within the range of possibility. They are however more conservative in that they imply a higher infiltration rate than the one from this study. The distribution of chloride deposition rates across the study area was obtained by applying the mean chloride concentration to the mean annual precipitation rate for each surface gridblock. The concentration generally reflects the inverse of the infiltration-high concentration in alluvial washes, as well as lower concentrations along the ridge top of Yucca Mountain and regions to the northwest 
of the Solitario Canyon Faults, where higher precipitation and infiltration occur. The water infiltration flux in the base-case study was taken from the present-day mean infiltration map shown in Fig. 3 (Wu et al., 2000).

To reflect the predicted future climate changes and to model the long-term chloride evolution, a possible future climate change to a much wetter glacial period was implemented based on the evapotranspiration model for Yucca Mountain (Hevesi et al., 1992; Flint and Flint, 1994; Flint et al., 1996). In this model, the precipitation rate increased by a factor of two over the modern rate, with a corresponding increase in the infiltration rate by a factor of five. The chloride concentration in the precipitation is assumed to be the same as that at present time, because there is no information on the relationship between chloride concentration and climate for Yucca Mountain area. This results in a factor of two increase in the chloride flux (deposition rate). If the chloride deposition rate was assumed to be constant, then the modeled chloride concentrations would be reduced to half their predicted values, which would result in much lower concentrations than those currently observed.

\subsection{Chloride transport simulation model}

In this model, the system was assumed to be under two-phase isothermal flow conditions for water and air. A three-dimensional dual-permeability model and the T2R3D version (Wu et al., 1996) of the TOUGH2 code (Pruess, 1991; Pruess et al., 1996) were employed for the simulations, with major chemical-transport processes taken into account. Fracture-matrix interaction was handled using the dual-permeability method. The dual-permeability methodology considered global flow and transport occurring not only between fractures but also between matrix gridblocks. In this approach, the rock-volume domain is represented by two overlapping fracture and matrix continua, and fracture-matrix flow and transport is approximated as quasi-steady state. In all steady-state simulations, the steady-state flow fields were first simulated, followed by chemical-transport simulations. Simulation grids are the same as those used in the 3-D UZ nonperched-water model described by Wu et al. (1999). The grids are refined in the vicinity of the proposed repository, located near the center of the model domain. Basic 
hydrologic properties for rock and fluids include: fracture properties (frequency, permeability, van Genuchten (1980) parameters, aperture, porosity, and interface area); matrix properties (porosity, permeability, and van Genuchten parameters); and transport properties (grain density, tortuosity, diffusion, decay and sorption coefficients), respectively, for each model layer. Special matrix and fracture properties are applied to faults in $\mathrm{TCw}, \mathrm{PTn}, \mathrm{TSw}$ and $\mathrm{CHn}$ units. The development of these parameters are presented in 3-D model properties studies (Ahlers and Liu, 2000; Wu et al., 2000). Boundary conditions for chemical components were treated similarly to those for flow simulations, with mass fluxes described at the top boundary and no-flow and water table conditions at the lateral and bottom boundaries, respectively. The hydraulic dispersivities for both fracture and matrix continua in the simulation were assumed to be zero, considering the coarseness of the grid and the use of first-order upstream weighting for transport (Sonnenthal and Bodvarsson, 1999). Diffusion coefficients used were those for chemical ions at $25^{\circ} \mathrm{C}$ and infinite dilution in water (Lasaga, 1998).

Chloride transient transport modeling was analyzed using an analytical solution for a one-dimensional semi-infinite chemical-transport system (Javandel et al., 1984):

$C(t, z)=C_{0}+\frac{1}{2}\left(C_{1}-C_{0}\right)\left[\operatorname{erfc}\left(\frac{z-v t}{2 \sqrt{D t}}\right)+\exp \left(\frac{v z}{D}\right) \operatorname{erfc}\left(\frac{z+v t}{2 \sqrt{D t}}\right)\right]$

where $C_{0}[\mathrm{mg} / \mathrm{L}]$ is the system initial chemical concentration at $t=0[\mathrm{~s}], C_{1}[\mathrm{mg} / \mathrm{L}]$ the concentration at depth $z=0[\mathrm{~m}], v[\mathrm{~m} / \mathrm{s}]$ the pore velocity, and $D\left[\mathrm{~m}^{2} / \mathrm{s}\right]$ the dispersion coefficient. The dispersion coefficient is defined by

$$
D=\alpha v+D_{m}
$$

with the dispersivity $\alpha[\mathrm{m}]$ and the molecular diffusion coefficient $D_{m}\left[\mathrm{~m}^{2} / \mathrm{s}\right]$.

\section{Flow and transport process calibration and analyses}

\subsection{Infiltration calibration}

Infiltration calibration proceeded by dividing the surface-infiltration area into nine 
regions according to the availability and range of chloride data, the range of present-day mean net infiltration data, and the hydrogeologic and hydrostructural features. Chloride field data were assigned to corresponding simulation cells, based on porewater sample locations and averaged if multiple data exist within one cell. The total water infiltration flux $f_{w}[\mathrm{~kg} / \mathrm{s}]$ of each region is calculated by:

$f_{w}=f_{c l}\left(10^{3} \rho / C_{c l}-1\right)$

where $f_{c l}[\mathrm{~kg} / \mathrm{s}]$ is the total chloride infiltration flux of the region, $C_{c l}[\mathrm{mg} / \mathrm{L}]$ the averaged chloride concentration of the region from the chloride data, and $\rho\left[\mathrm{kg} / \mathrm{m}^{3}\right]$ the aqueous-phase density. The calculated total water-infiltration flux is then allocated to each surface cell according to the cell surface area. The map of calibrated infiltration is shown in Fig. 4. Averaged present-day mean infiltration (Flint et al. 1996) was applied to regions where chloride data are unavailable (Regions I, II, and VIII). The overall and regional infiltration volume, and infiltration rates of the two infiltration schemes were compared and given in Table 1.

Three-dimensional flow and chloride transport simulations were conducted using the present-day mean infiltration (Fig. 3) and the calibrated present-day mean infiltration (Fig. 4) to assess the two infiltration schemes. Figures 5-7 show the comparisons of model results of steady-state chloride concentrations with measured porewater chloride concentration data along the ESF, ECRB stations where the monitoring instruments are located, and borehole UZ\#16, respectively. Compared to the data, the model results using the present-day mean infiltration are higher at the North Ramp (0-2,000 m), South Ramp (6,400 m-8,000 m), northeast ECRB (left side of the figure), and borehole UZ\#16; and lower at southwest ECRB (right side of the figure). To examine the cause of these differences, we plotted the infiltration rates along the ECRB in Fig. 8. As can be seen, higher modeled chloride concentrations at northeast ECRB correspond to very low infiltration rates, while much higher infiltration rates lead to lower modeled chloride concentrations at southwest ECRB. In Fig. 9, with a logarithmic scale, we plotted the distribution of chloride concentration in infiltrated water along the ECRB. The infiltration chloride concentrations vary significantly compared to the rather smooth concentration 
data at the same location. This inconsistency is not expected for a system dominated by vertical flow. Simulated percolation fluxes using the present-day mean infiltration and calibrated present-day mean infiltration along the ECRB station are shown in Fig 10. Surface water infiltration fluxes represented by the two schemes along the tunnel are also shown in the same figure. The impact of infiltration changes on the percolation fluxes seems insignificant compared to that on the chloride concentration distributions at the same location shown in Fig. 6. This observation was further confirmed by an analysis of overall percolation flux distributions at the repository and water table as well as chloride concentration in the system. Figs. 11 and 12 correlate the percolation fluxes on the and the flux area frequency distribution. Area frequencies are generated by grouping the vertical flux results at the corresponding places, counting the total found in each group, and then calculating the percent contribution relative to the total horizontal area in each category. Fig. 13 shows the same analysis of chloride concentration in the system with volume weighting applied. Chloride concentration distributions using the calibrated present-day mean infiltration matches the field data better than that using the present-day mean infiltration, although the percolation flux distribution by the two infiltration schemes are very similar at both the repository and the water table.

Model results at the same locations using the calibrated infiltration are closer to the chloride field data than those using present-day mean infiltration. Absolute differences between model results and measured field chloride data are calculated and shown in Fig. 14. Overall, smaller differences are obtained when the calibrated infiltration rates are used instead of the present-day mean infiltration rates from Flint et al. (1996).

\subsection{Chloride transient transport analyses}

For transport dominated by vertical flow, we applied the one-dimensional analytical solution to chloride transient calculations. Along ESF and ECRB stations, 1-D columns were extracted from a 3-D simulation model domain. The extraction started from the model surface and ended in the middle of the cell where the station was located. Average column porosity was calculated by the total pore volume and bulk volume of the column, including both fracture and matrix volumes. Transport parameters were the same as those 
used in the simulations. Column pore velocities were calculated based on the infiltration rates and average column porosity. Chloride concentrations at each column surface boundary were chloride infiltration concentrations. Below the surface boundary, zero initial chloride concentrations and glacial infiltration were first applied to estimate a glacial steady-state distribution of chloride concentrations in the subsurface. These concentrations were then used as initial concentrations, along with the calibrated presentday mean water infiltration and chloride infiltration concentrations, to calculate chloride distributions.

The analytical solutions were first verified by 3-D transport simulation results. Fig. 15 shows good agreement in the comparisons of ESF chloride concentrations at 15,000 years and present time by the two methods. Steady-state flow fields for both glacial and present times were used in this verification case.

Chloride transient concentrations at ESF and ECRB stations were computed, with the results given in Figs. 16 and 17. Compared with the measured data, the analytical solutions are within the range of measured data and able to catch major chloride transient transport behavior and trends.

\subsection{PTn lateral flow effects}

The PTn consists of nonwelded and vitric horizons and bedded tuffs intersected by faults and fault zones. The percolation distribution in the potential repository level below the PTn determines the degree of seepage into drifts, which in turn affects the performance of waste packages and engineered barrier systems. To study the effect of PTn lateral flow on the degree of damping of flux variability introduced at the surface, and on the distribution of chloride concentrations, three-dimensional simulations were conducted with increased PTn horizontal permeability (i.e., ratios of horizontal permeability to vertical permeability 10 and 100 , respectively).

Figures 18-20 compare field data with the model results of chloride concentrations in the ESF and ECRB, and in borehole UZ\#16. The "kh/kv=1" case shown in the figures is the one without changing the PTn permeability field (as in the original model). The damping effects, varying in different locations, are visible in the figures showing the 
North Ramp, south Main Drift, and northeast ECRB. As horizontal permeability is increased, the simulated chloride concentrations in borehole UZ\#16 below the PTn hydrogeologic units are reduced and become closer to the measured chloride data from porewater samples. Decreased simulated chloride concentrations were also observed at boreholes NRG-6, NRG-7A, SD-7, SD-12, and UZ\#4 as the PTn permeability was altered. Few changes were found, however, at boreholes SD-9 and UZ-14. Because the water infiltration and chloride infiltration concentrations are the same for the three simulation cases of different three permeability fields, significant changes in overall chloride distributions in the systems are not expected as shown in Fig. 21, which are the frequencies of chloride concentration distribution corresponding to the three PTn permeability fields. In general, the cases with increased PTn lateral flow match the chloride data better than the case with the original PTn permeability field. To achieve a more realistic and physically meaningful model, however, further studies are needed to conduct detailed calibrations of the PTn permeability field, based on the available chemical distribution data.

\section{Conclusions}

Porewater chloride concentration data were analyzed and used to calibrate the present-day mean infiltration in Yucca Mountain flow and transport model. The surface infiltration area was divided into regions according to the availability and range of chloride data, the range of present-day mean infiltration data, and hydrostructural and hydrogeological features. Infiltration rates in each region were calculated based on the averaged porewater chloride concentration data of the region. Model results of threedimensional simulation using the calibrated infiltration map match the chloride data better than using the uncalibrated infiltration map. Statistical analyses on the frequency distribution of overall percolation fluxes and chloride concentration in the system were conducted, with the results demonstrating that the impact of infiltration changes on the percolation fluxes are insignificant compared to that on the chloride concentration distributions. The distribution of chloride concentration in the infiltrating water is the main factor controlling chloride transport processes in the UZ system. 
Chloride transient flow was modeled by analytical methods, using analytical solutions for a one-dimensional semi-infinite chemical-transport system. The method was verified by good agreement between analytical solutions and 3-D simulations under the same flow and transport conditions. Compared with chloride concentration data, transient solutions at different times were able to capture major chloride transport behavior and trends of chemical movements.

PTn lateral flow effects on water flux and chloride distribution were studied by 3-D simulation with increased horizontal permeability. The degree of the effects varied by location. As expected, a more uniform chloride distribution under the PTn was observed in most places when lateral flow effects increased. Further calibration can be done by adjusting layer heterogeneity and anisotropic permeability in different regions, based on hydrostructural features, percolation fluxes, and the distribution of geochemical data.

Combined results from these model calibrations furnish important information for the UZ model studies, contributing to the performance assessment of the proposed repository system.

\section{Notation}

$C_{0} \quad$ Initial chemical concentration in the system, $\mathrm{mg} / \mathrm{L}$

$C_{c l} \quad$ Chloride concentration in the system, $\mathrm{mg} / \mathrm{L}$

$C_{1} \quad$ Chemical concentration at surface boundary, $\mathrm{mg} / \mathrm{L}$

$D \quad$ Dispersion coefficient, $\mathrm{m}^{2} / \mathrm{s}$

$D_{m} \quad$ Molecular diffusion coefficient, $\mathrm{m}^{2} / \mathrm{s}$

$f_{c l} \quad$ Chloride infiltration flux, $\mathrm{kg} / \mathrm{s}$

$f_{w} \quad$ Water infiltration flux, $\mathrm{kg} / \mathrm{s}$

$\mathrm{t} \quad$ Time, $\mathrm{s}$

z Depth, $\mathrm{m}$

$v \quad$ Fluid pore velocity, $\mathrm{m} / \mathrm{s}$

$\alpha \quad$ Dispersivity, $\mathrm{m}$

$\rho \quad$ Density of aqueous phase, $\mathrm{kg} / \mathrm{m}^{3}$ 


\section{Acknowledgement}

We would like to thank Huihai Liu, Patrick Dobson and Dan Hawkes for their review of this paper. We are also indebted to June Fabryka-Martin and William Stone for their insightful and constructive comments during the JCH review. This work was supported by the Director, Office of Civilian Radioactive Waste Management, U. S. Department of Energy, through Memorandum Purchase Order EA9013MC5X between TRW Environmental Safety Systems Inc. and the Ernest Orlando Lawrence Berkeley National Laboratory. The support is provided to Lawrence Berkeley National Laboratory through the U. S. Department of Energy Contract No. DE-AC03-76SF00098.

\section{References}

Ahlers, C. F. and Liu, H. H., 2000. Analysis of hydrologic properties data. ANL-NBSHS-000002, Civilian Radioactive Waste Management System Management \& Operating Contractor (CRWMS M\&O), Las Vegas, Nevada.

Allison, G. B., and Hughes, M, W., 1978 The use of environmental chloride and tritium to estimate total recharge to an unconfined aquifer, Aust. J. Soil Res., 16, 181-195.

Clayton, R.W., 2000. Geologic Framework Model (GFM3.1). MDL-NBS-GS-000002 REV 00 ICN 01, Las Vegas, Nevada, CRWMS M\&O.

Fabryka-Martin, J.T., Meijer, A., Marshall, B., Neymark, L., Paces, J., Whelan, J., Yang, A., 2000. Analysis of Geochemical Data for the Unsaturated Zone, ANL-NBS-HS000017; OCRWM M\&O.

Fabryka-Martin, J.T., Wolfsberg, A.V., Levy, S.S., Campbell, K., Tseng, P., Roach, J.L., Wolfsberg, L.E., 1998. Evaluation of flow and transport models of Yucca Mountain, based on chlorine-36 and chloride studies for FY98. Los Alamos Report LA-CSTTIP-98-007, LANL Milestone SP33DDM4. Los Alamos National Laboratory, Los Alamos, NM.

Fabryka-Martin, J.T., Flint, A.L., Sweetkind, D.S., Wolfsberg, A.V., Levy, S.S., Roach, J.L., Woldegabriel, G., Wolfsberg, L.E., 1997. Evaluation of flow and transport models of Yucca Mountain, based on chlorine-36 and chloride studies for FY97. Los Alamos Report LA-CST-TIP-97-010, LANL Milestone SP2224M3. Los Alamos National Laboratory, Los Alamos, New Mexico.

Fabryka-Martin, J.T., Wolfsberg, A.V., Dixon, P.R., Levy, S.S., Musgrave, J., Turin, H.J., 1996. Summary report of chlorine-36 studies: sampling, analysis and simulation of chlorine-36 in the exploratory studies facility. Los Alamos National Laboratory Milestone Report 3783M. Los Alamos National Laboratory, Los Alamos, New Mexico.

Fabryka-Martin, J.T., Wightman, S.J., Robinson, B.A., Vestal, E.W., 1994. Infiltration processes at Yucca Mountain inferred from chloride and chlorine-36 distributions. Los Alamos Report LA-CST-TIP-98-022. Los Alamos National Laboratory, Los Alamos, New Mexico. 
Flint, A.L., Flint, L.E., Bodvarsson, G.S., Kwicklis, E.M., and Fabryka-Martin, J.(2001). Evolution of the conceptual model of unsaturated zone hydrology at Yucca Mountain, Nevada. Journal of Hydrology, 247(1-2): 1-30.

Flint, L.E., 1998. Matrix properties of hydrogeologic units at Yucca Mountain, Nevada. U.S. Geological Survey Report 97-4243. . U. S. Geol. Surv. Water-Resour. Invest. Rep. Denver, Colorado.

Flint, A.L., Hevesi, J.A., Flint, L.E., 1996. Conceptual and numerical model of infiltration for the Yucca Mountain Area, Nevada. Milestone 3GU1623M. U. S. Geol. Surv. Water-Resour. Invest. Rep. Denver, Colorado.

Flint, A.L., Flint, L.E., 1994. Spatial distribution of potential near surface moisture flux at Yucca Mountain. Proceedings of the Fifth Annual International Conference on High Level Radioactive Waste Management, Vol. 4. American Nuclear Society, Las Vegas, Nevada, p. 2352-2358.

Geomatrix Consultants, 1997. Unsaturated Zone Flow Model Expert Elicitation Project, Yucca Mountain, NV, GMX No. 3997.

Hevesi, J.A., Flint, A., L., Istock, J.D., 1992. Precipitation estimation in mountainous terrain using multivariate geostatistics: Part II. Isohyetal maps. Journal of Applied Meteorology 31, 677-688.

Hinds, J. and Pan, L., 2000. Development of Numerical Grids for UZ Flow and Transport Modeling, Report ANL-NBS-HS-000015; Rev 00, Lawrence Berkeley National Laboratory, OCRWM M\&O.

Javandel, I., Doughty, C., Tsang, C.F., 1984. Groundwater Transport: Handbook of Mathematical Models, American Geophysical Union, Washington, D.C.

Johnson, T.M., DePaolo, D.J., 1994. Interpretation of isotopic data in groundwater systems: model development and application to $\mathrm{Sr}$ isotopic data from Yucca Mountain, Water Resour. Res. 30, 1571-1587.

Lasaga, A.C., 1998. Kinetic Theory in the Earth Sciences, Princeton University Press, Princeton, New Jersey.

Meijer, A., 1995. Modeling and experimental results on saturated zone water chemistry, LANL Milestone 3387. Los Alamos National Laboratory, Los Alamos, New Mexico.

Pruess, K., Simmons, A., Wu, Y.S., Moridis, G.J., 1996. TOUGH2 Software Qualification Report. Report LBL-38383. Lawrence Berkeley National Laboratory, Berkeley, California.

Pruess, K., 1991. TOUGH2-a general purpose numerical simulator for multiphase fluid and heat flow. Report LBL-29400. Lawrence Berkeley National Laboratory, Berkeley, California.

Scanlon, B.R., 2000. Uncertainties in estimating water fluxes and residence times using environmental tracers in an arid unsaturated zone. Water Resour. Res. 36 (2), 395409.

Sonnenthal, E.L., Bodvarsson, G.S., 1999. Constraints on the hydrology of the unsaturated zone at Yucca Mountain, NV from three-dimensional models of chloride and strontium geochemistry. J. Contam. Hydrol., 38, 107-156.

Triay, I.R., Meijer, A., Conce, J.L., Kung, K.S., Rundberg, R.S., Streitelmeier, E.A., 1996. Summary and Synthesis Report on Radionuclide Retardation for the Yucca Mountain Site Characterization Project. Milestone 3784M. Los Alamos National Laboratory, Los Alamos, New Mexico. 
Tyler, S.W., Chapman, J.B., Conrad, S.H., Hammermeister, D.P., Blout, D.O., Miller, J.J., Sully, M.J., Ginanni, J.M., 1996. Soil-Water Flux in the Southern Great Basin, United States: Temporal and Spatial Variations Over the Last 120,000 Years. Water Resour. Res. 32 (6), 1481-1499

van Genuchten, M. Th., 1980. A closed-form equation for predicting the hydraulic conductivity of unsaturated soils. Soil Sci. Soc. Amer. J., 44(5), pp.892-898.

Wu, Y. S., Liu, J., Xu, T., Haukwa, C., Zhang, W., Liu, H. H. and Ahlers, C. F., 2000. UZ flow models and submodels, Report MDL-NBS-HS-000006, CRWMS M\&O, Las Vegas, Nevada.

Wu, Y.S., Haukwa, C., Bodvarsson, G.S., 1999. A site-scale model for fluid and heat flow in the unsaturated zone at Yucca Mountain, Nevada. J. Contam. Hydrol., 38, 185-215.

Wu, Y.S., Ahlers, C.F., Fraser, P., Simmons, A., Pruess, K., 1996. Software qualification of selected TOUGH2 modules. Report LBNL-39490. Lawrence Berkeley National Laboratory, Berkeley, California.

Yang, I.C., Yu, P., Rattray, G.W., Ferarese, J.S., Ryan, J.N., 1998. Hydrochemical Investigations in Characterizing the Unsaturated Zone at Yucca Mountain, Nevada. U.S. Geol. Surv. Water Resour. Invest. Rep. 98-4132, Denver, Colorado.

Yang, I.C., Rattray, G.W., Yu, P., 1996. Interpretation of Chemical and Isotopic Data from Boreholes in the Unsaturated Zone at Yucca Mountain, Nevada. U. S. Geol. Surv. Water-Resour. Invest. Rep. 96-4058, U.S. Geological Survey, Denver, Colorado.

Table 1. Infiltration data by region

\begin{tabular}{|c|c|c|c|c|c|c|c|c|}
\hline Region & \multicolumn{2}{|c|}{ Area } & \multicolumn{4}{c|}{ Net Infiltration Volume } & \multicolumn{2}{c|}{ Net Infiltration Rate } \\
\hline & \multicolumn{2}{|c|}{} & \multicolumn{2}{c|}{ Before Calibration } & \multicolumn{2}{c|}{ After Calibration } & Before Calibration & After Calibration \\
\cline { 2 - 9 } & $\mathrm{km}^{2}$ & $\%$ & $\mathrm{~m}^{3} / \mathrm{yr}$ & $\%$ & $\mathrm{~m}^{3} / \mathrm{yr}$ & $\%$ & $\mathrm{~mm} / \mathrm{yr}$ & $\mathrm{mm} / \mathrm{yr}$ \\
\hline I & 9.9 & 25.5 & 104435 & 58.9 & 104436 & 57.2 & 10.57 & 10.57 \\
\hline II & 5.3 & 13.8 & 12317 & 6.9 & 12317 & 6.8 & 2.31 & 2.31 \\
\hline III & 3.7 & 9.6 & 26266 & 14.8 & 26352 & 14.4 & 7.10 & 7.12 \\
\hline IV & 3.6 & 9.4 & 8819 & 5.0 & 8425 & 4.6 & 2.43 & 2.32 \\
\hline V & 4.6 & 11.9 & 12510 & 7.1 & 14075 & 7.7 & 2.71 & 3.05 \\
\hline VI & 2.2 & 5.6 & 2479 & 1.4 & 3973 & 2.2 & 1.14 & 1.83 \\
\hline VII & 1.8 & 4.6 & 3345 & 1.9 & 3345 & 1.8 & 1.88 & 1.88 \\
\hline VIII & 3.0 & 7.7 & 2156 & 1.2 & 2156 & 1.2 & 0.73 & 0.73 \\
\hline IX & 4.7 & 12.0 & 4996 & 2.8 & 7391 & 4.1 & 1.07 & 1.59 \\
\hline Overall & 38.7 & 100.0 & 177323 & 100.0 & 182470 & 100.0 & 4.58 & 4.71 \\
\hline
\end{tabular}




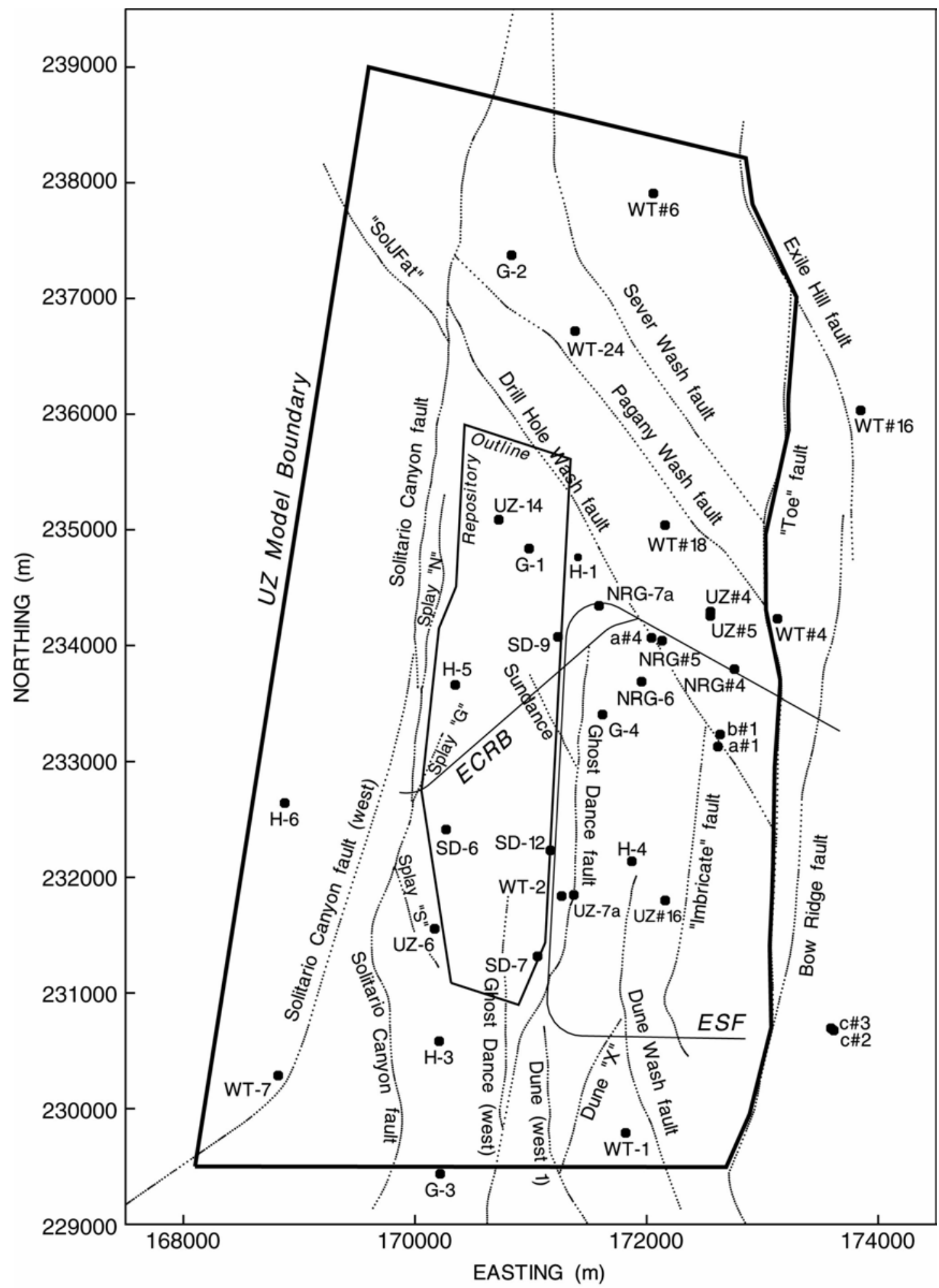

Fig. 1. Area map of the region enclosing Yucca Mountain, Nevada (Hinds and Pan, 2000). 


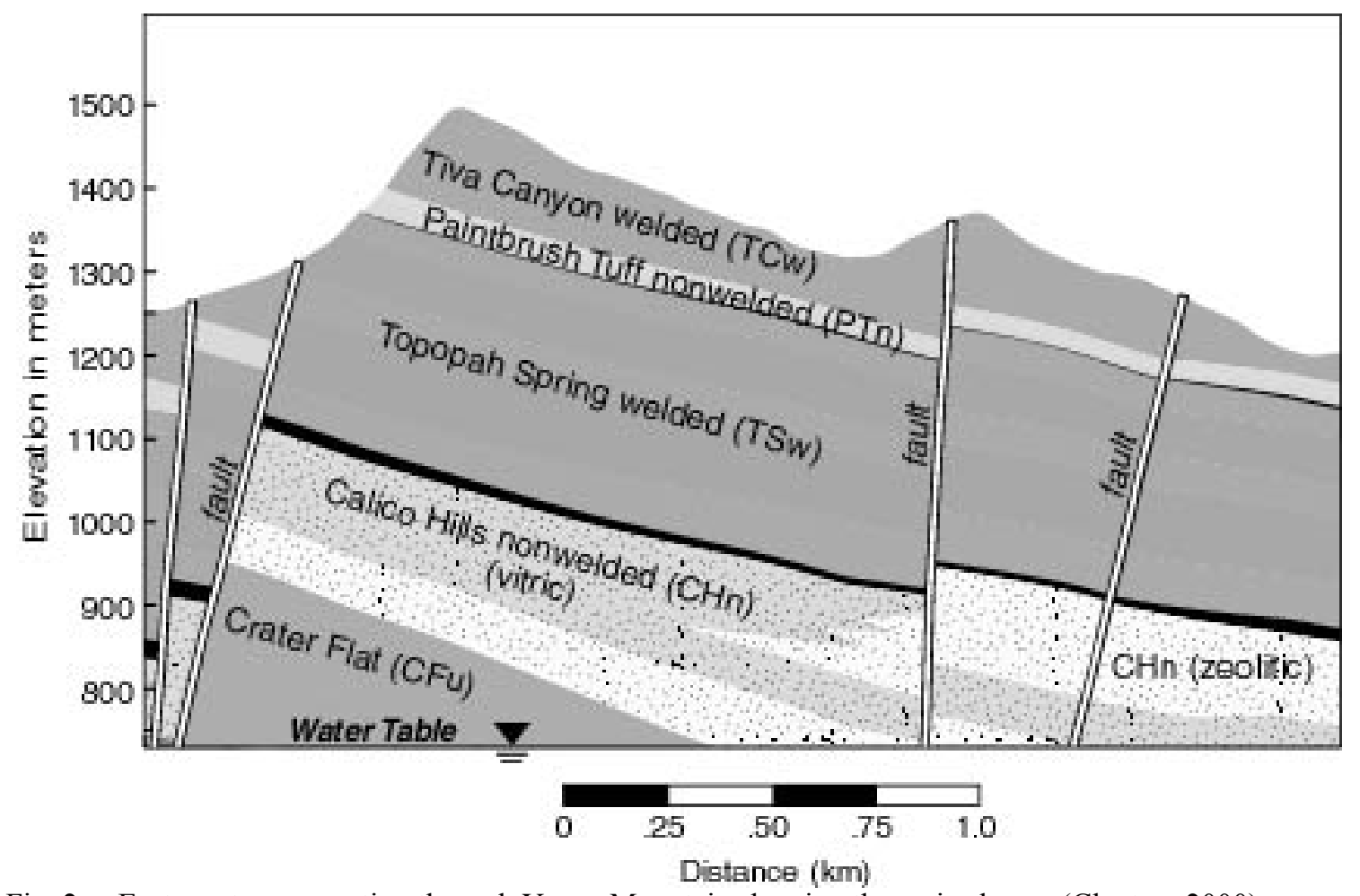

Fig. 2. East-west cross-section through Yucca Mountain showing the major layers (Clayton, 2000). 


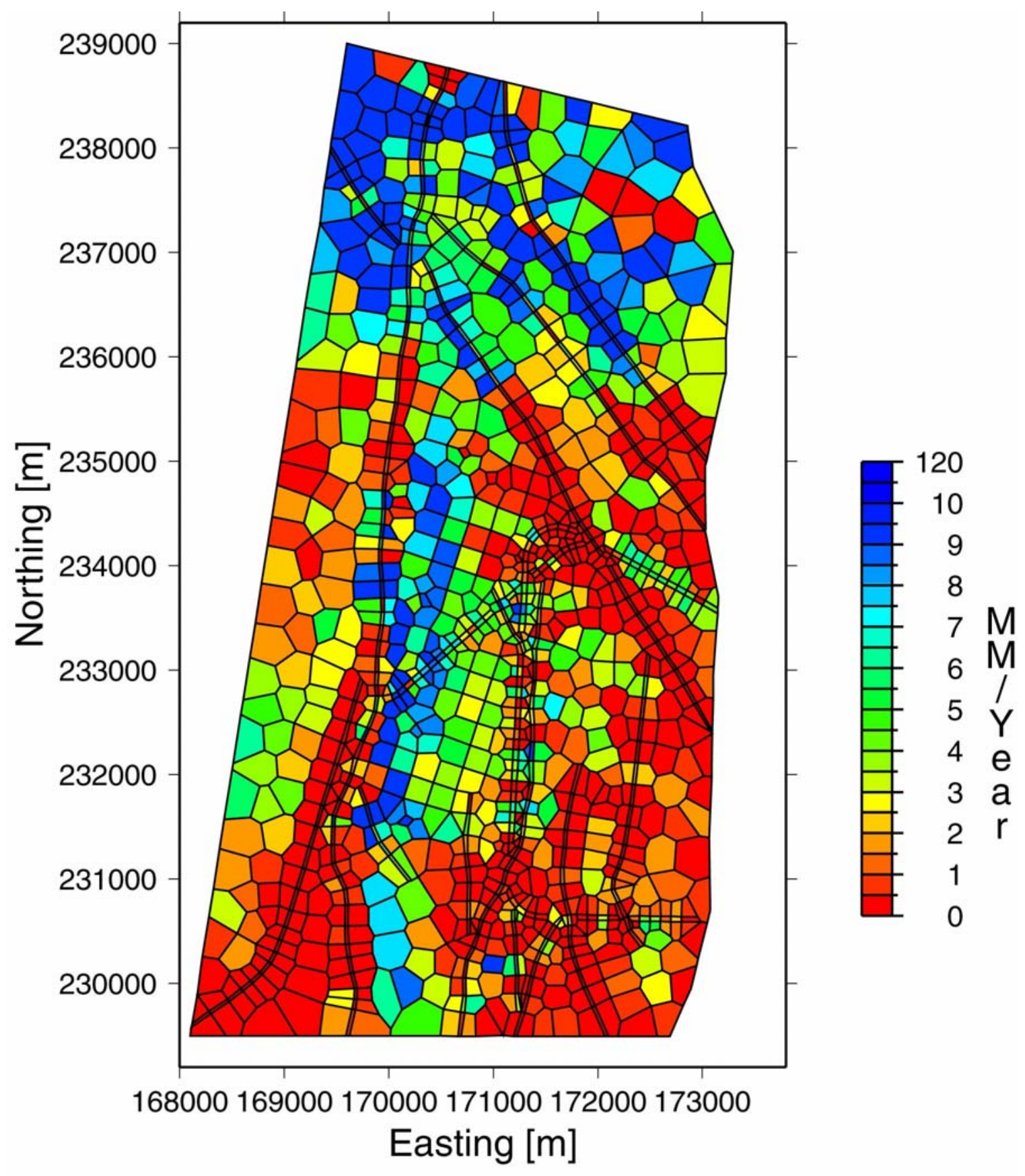

Fig. 3. Present-day mean infiltration (Wu et al. 2000). 


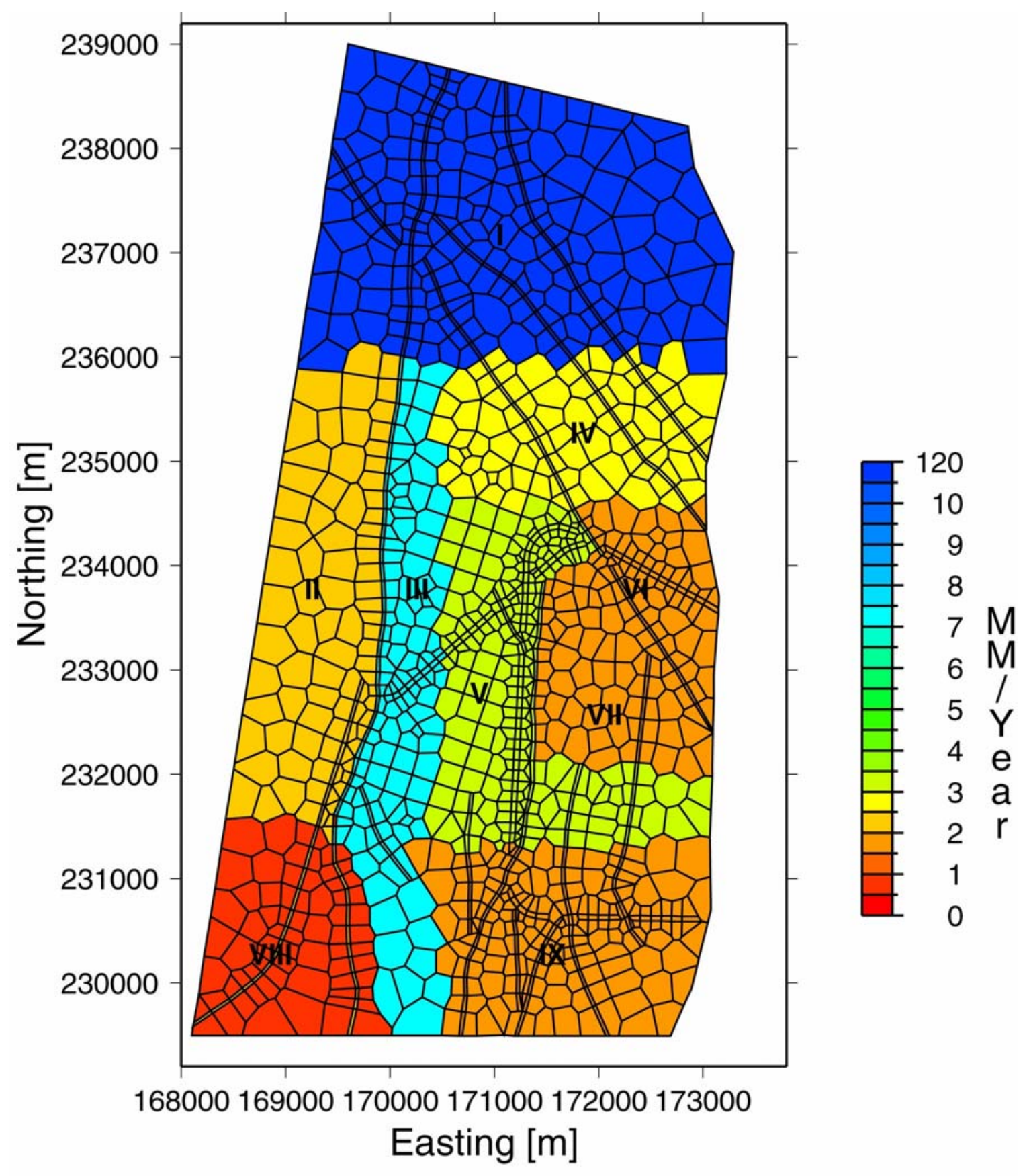

Fig. 4. Calibrated present-day mean infiltration. 


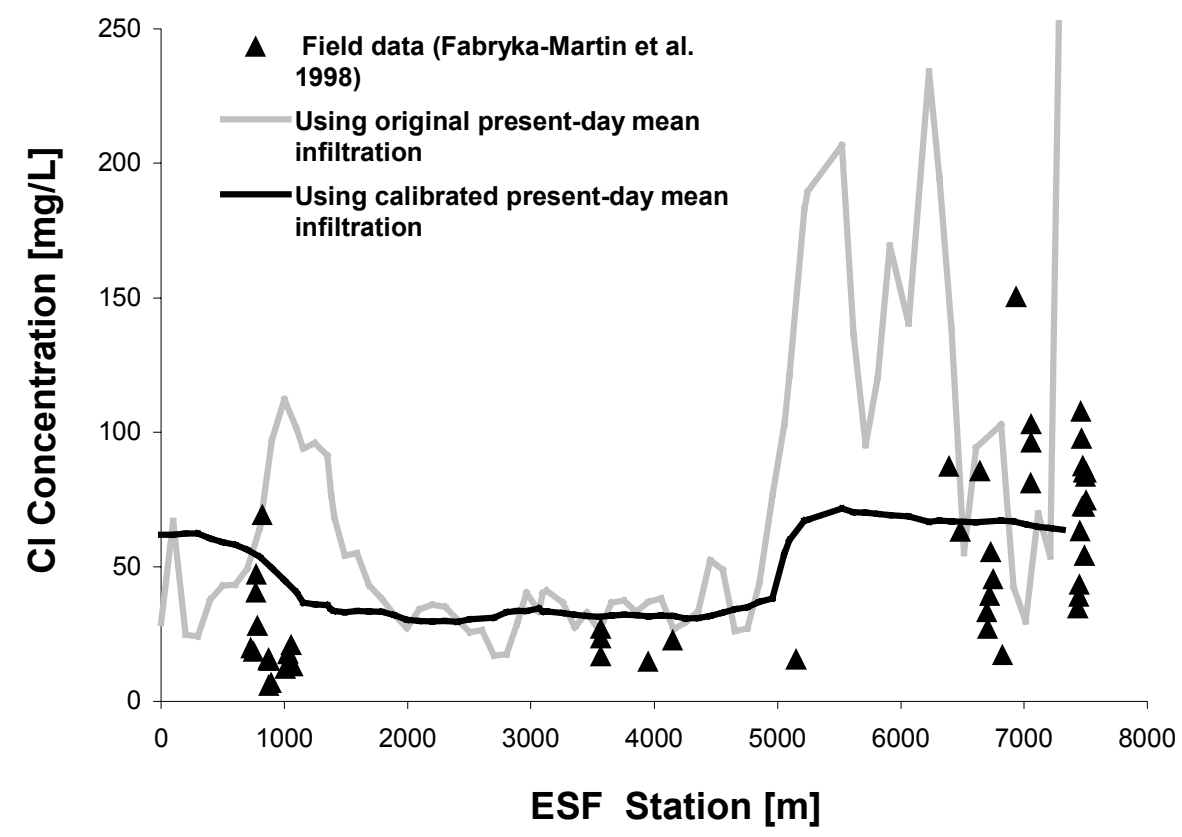

Fig. 5. ESF chloride model results using original and calibrated present-day mean infiltration rates.

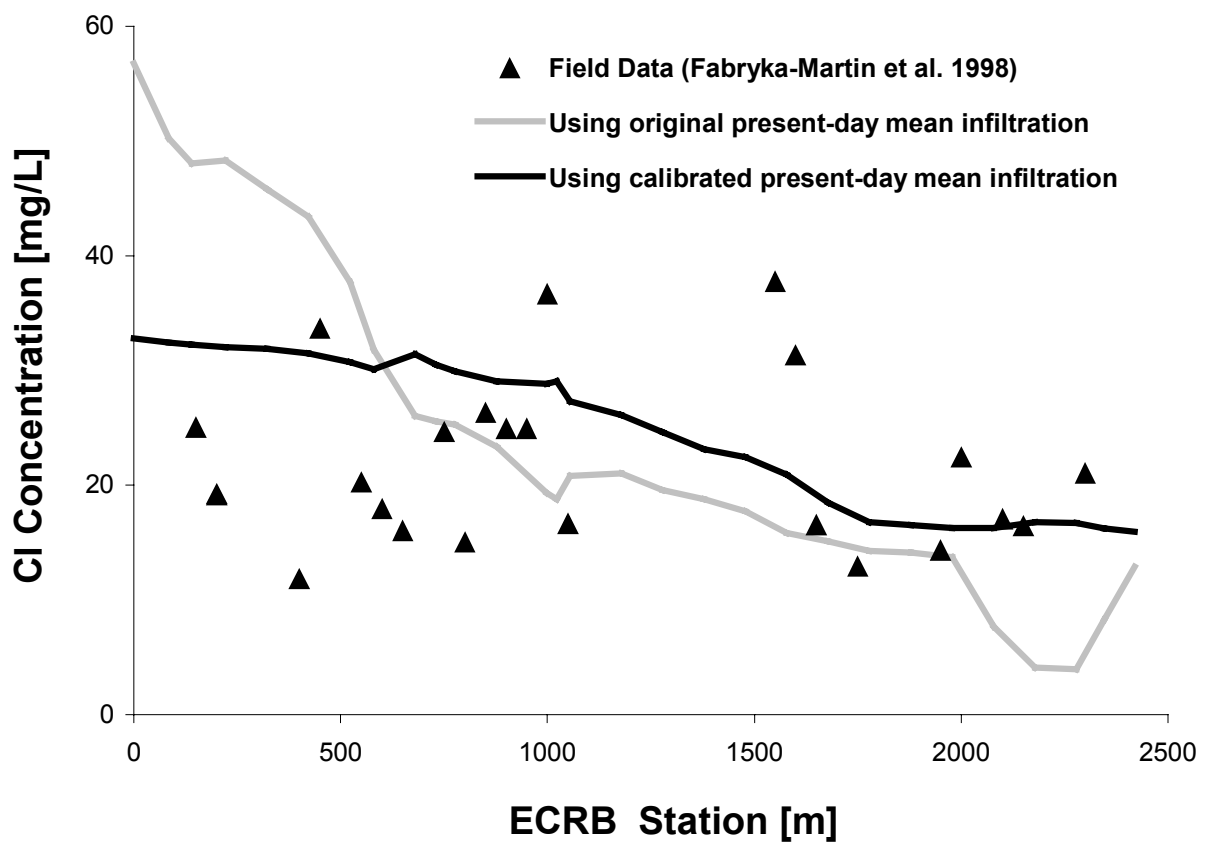

Fig. 6. ECRB chloride model results using original and calibrated present-day mean infiltration rates. 


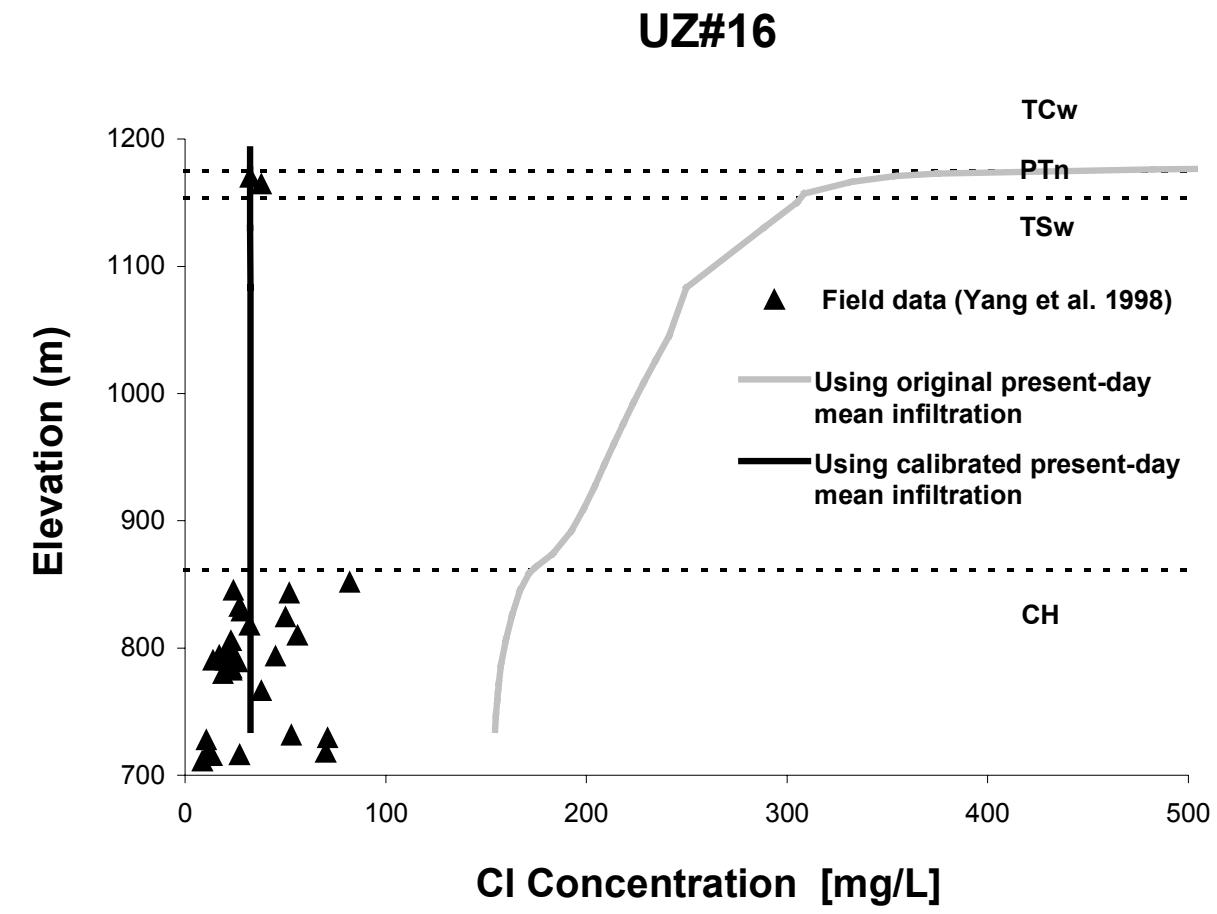

Fig. 7. Borehole UZ\#16 chloride model results using original and calibrated present-day mean infiltration rates.

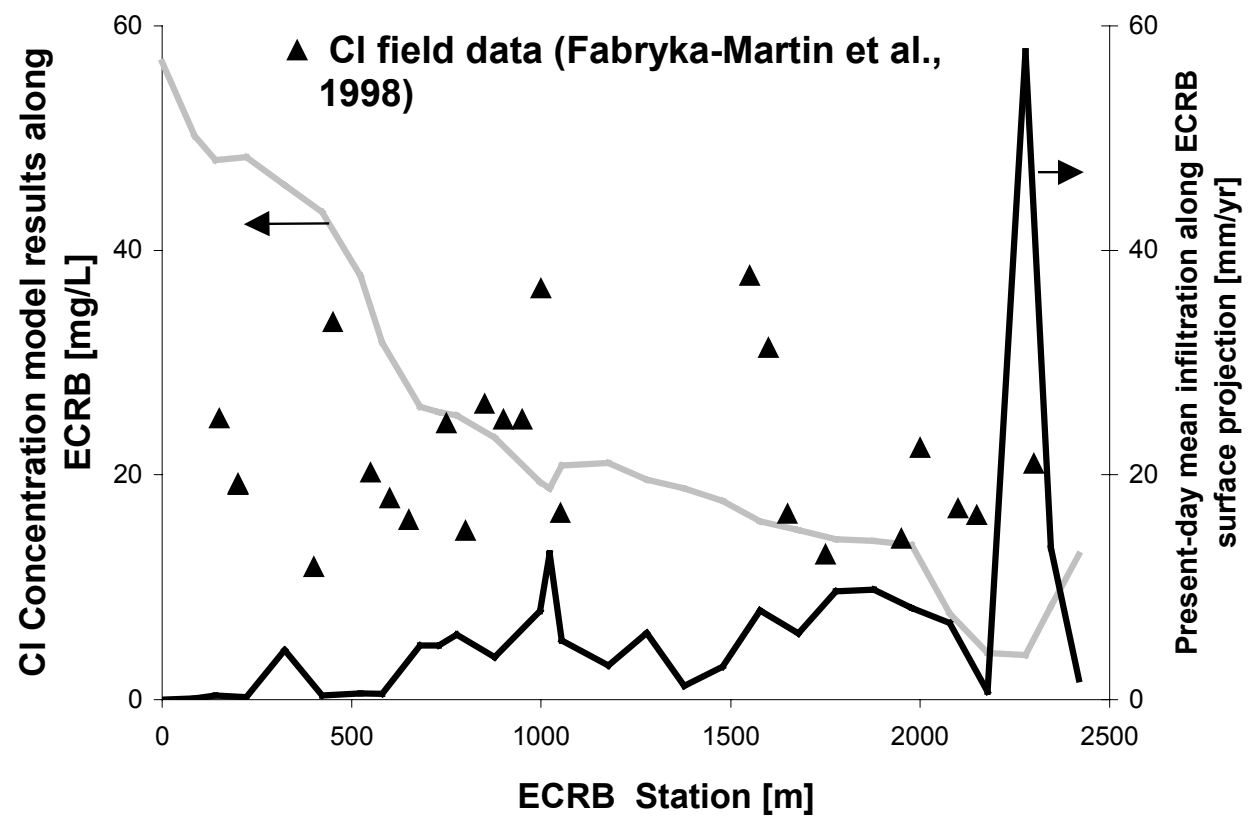

Fig. 8. Original present-day mean infiltration rates along the ECRB surface projection and chloride model results using the original present-day mean infiltration rates. 


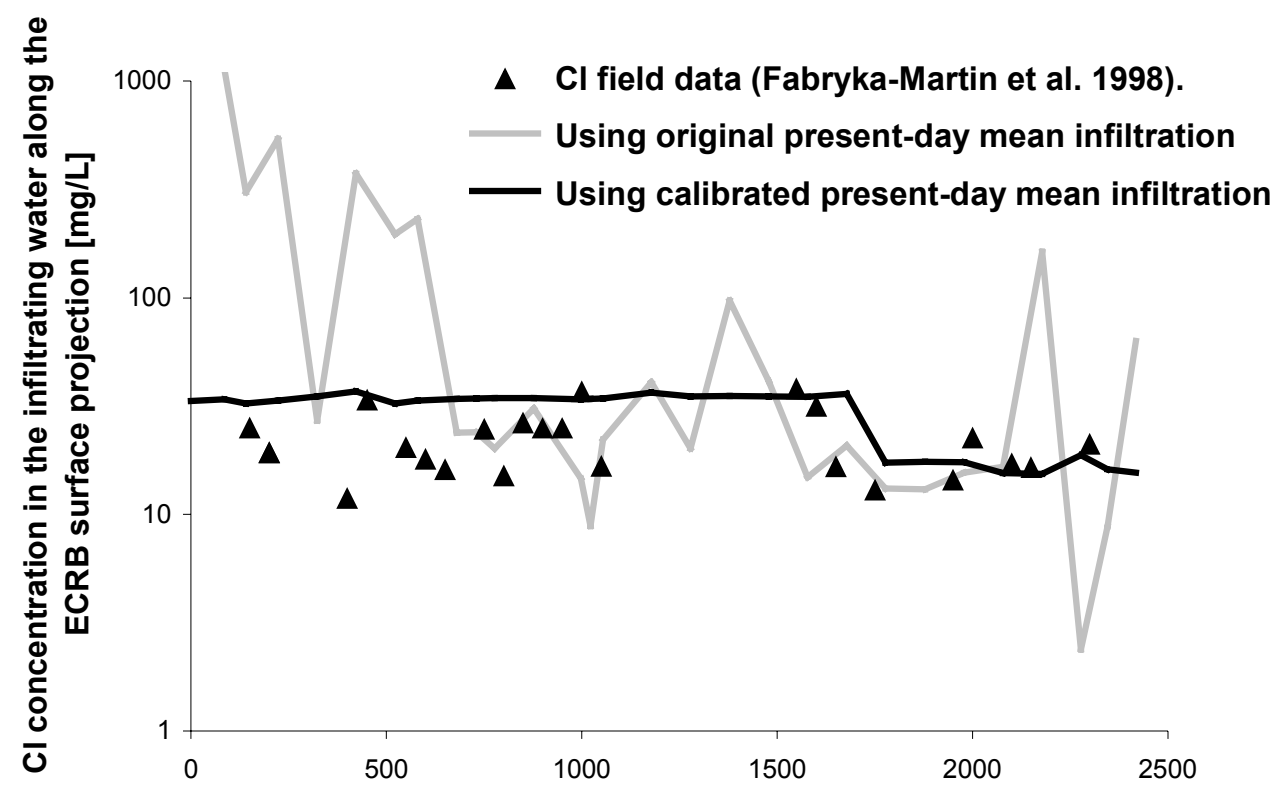

\section{ECRB Station [m]}

Fig. 9. Chloride concentration in the infiltrating water along ECRB surface projection.

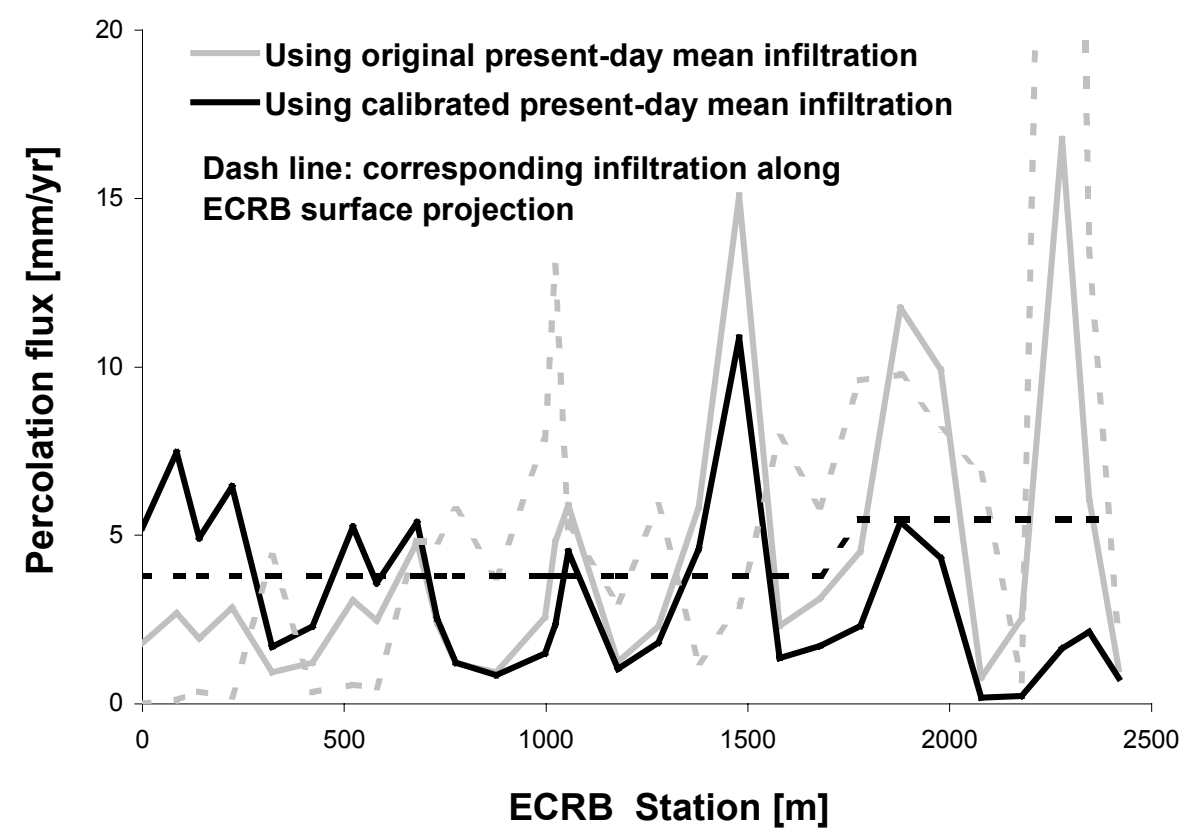

Fig. 10. ECRB percolation fluxes and the infiltration along ECRB surface projection. 


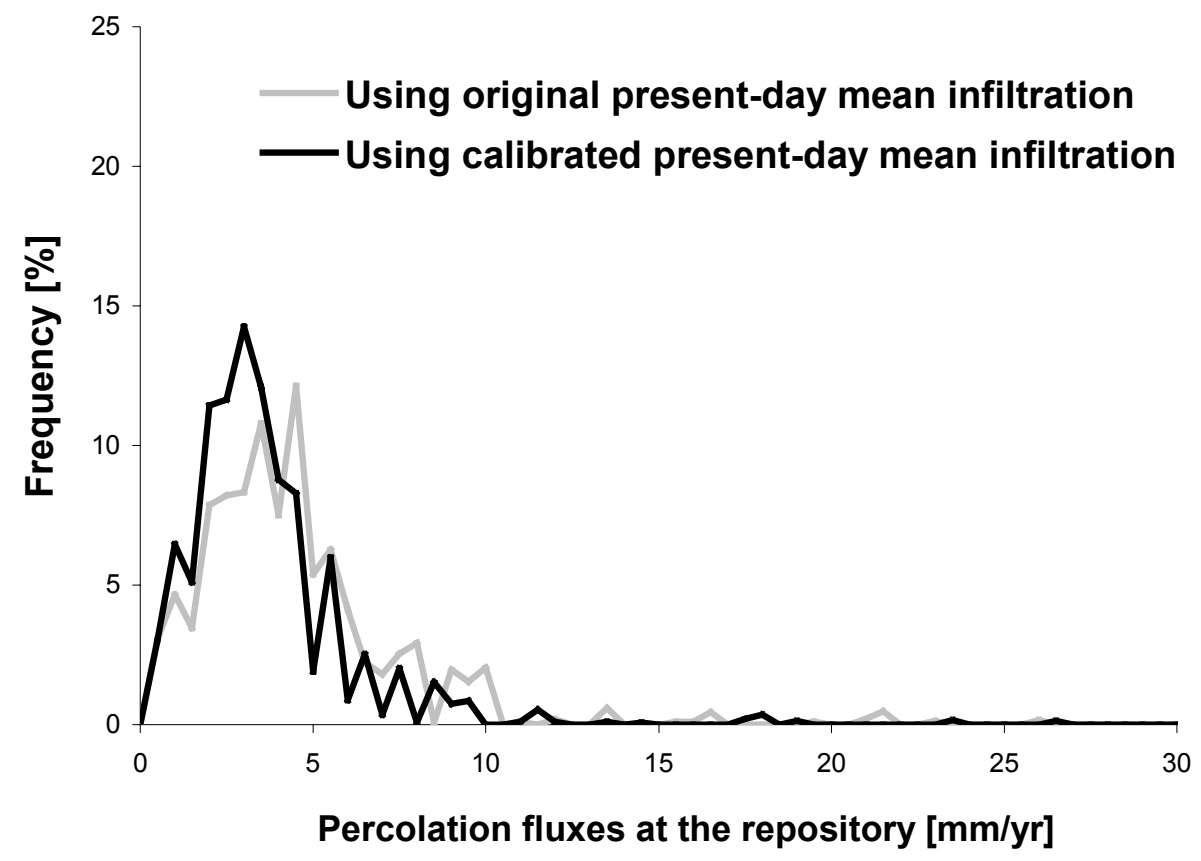

Fig. 11. Frequency of percolation flux distribution at the repository.

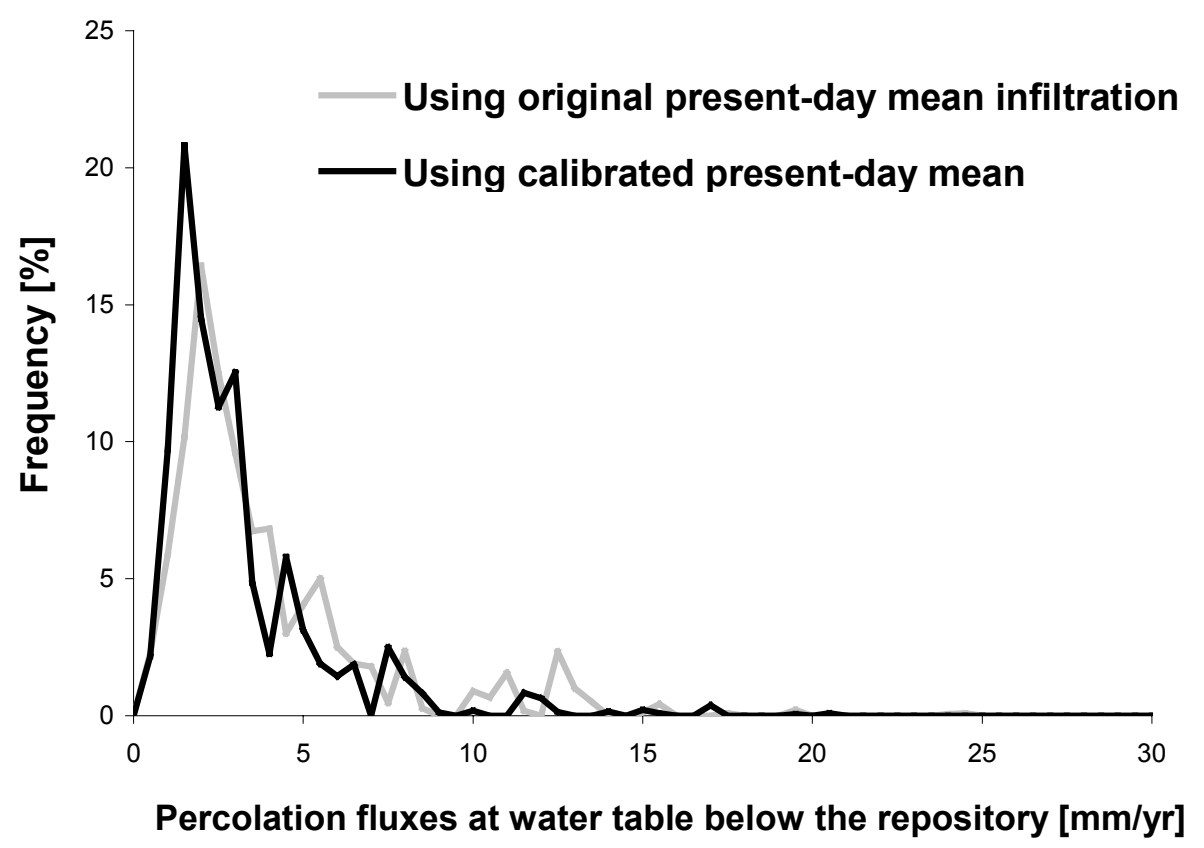

Fig. 12. Frequency of percolation flux distribution at water table below the repository. 


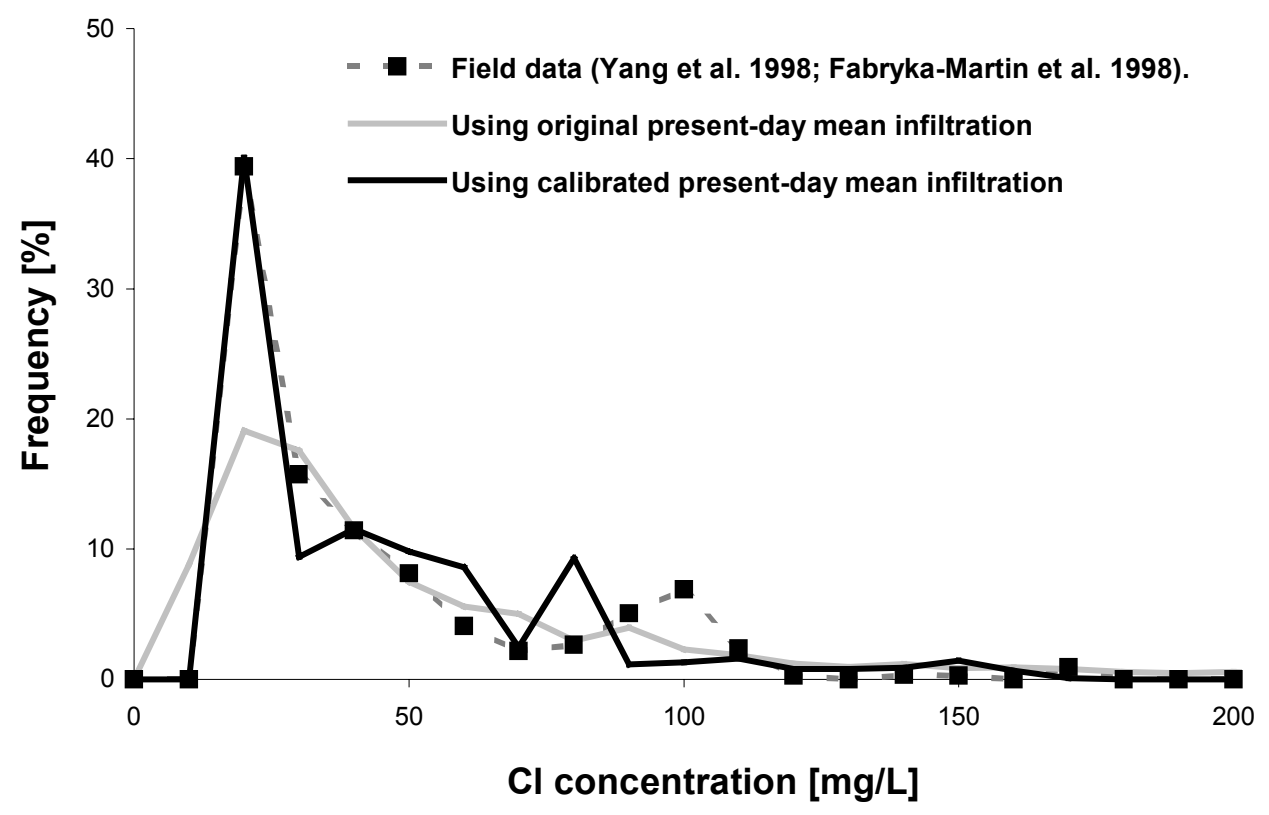

Fig. 13. Frequency of overall chloride distribution in the UZ system with calibrated infiltration. 


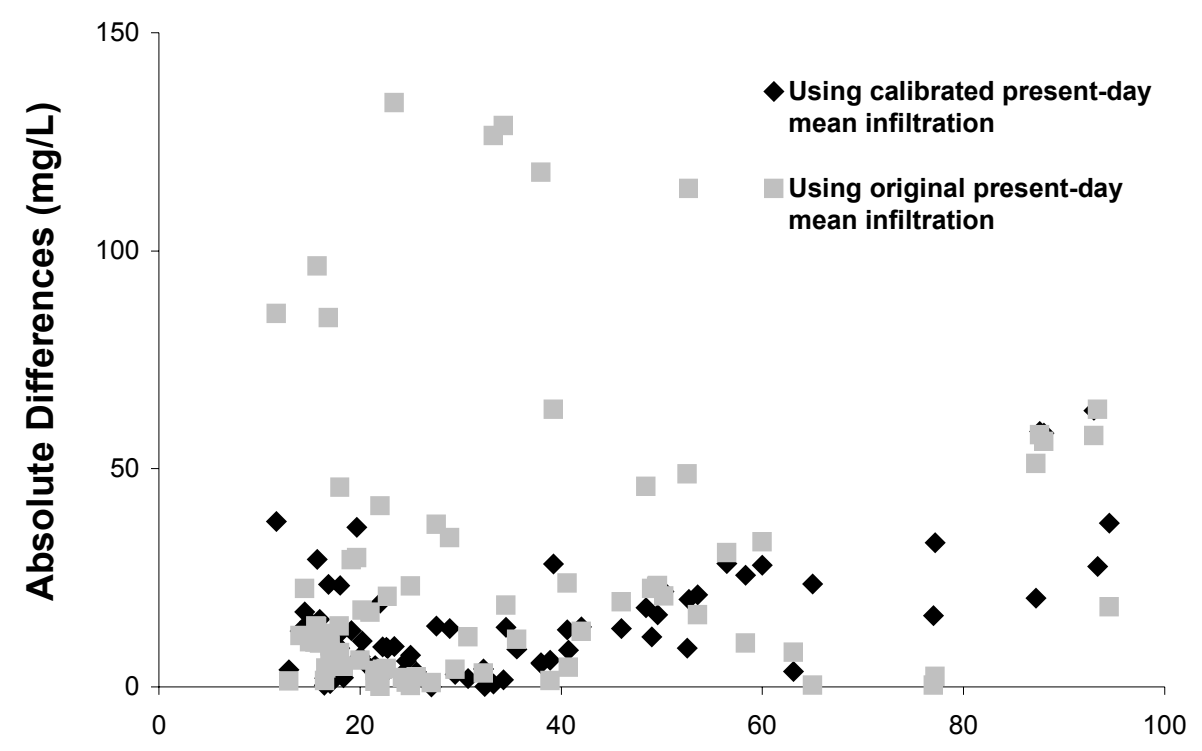

Field Data [mg/L] (Yang et al, 1998; Fabryka-Martin et al. 1998)

Fig. 14. Differences between chloride model results and chloride data.

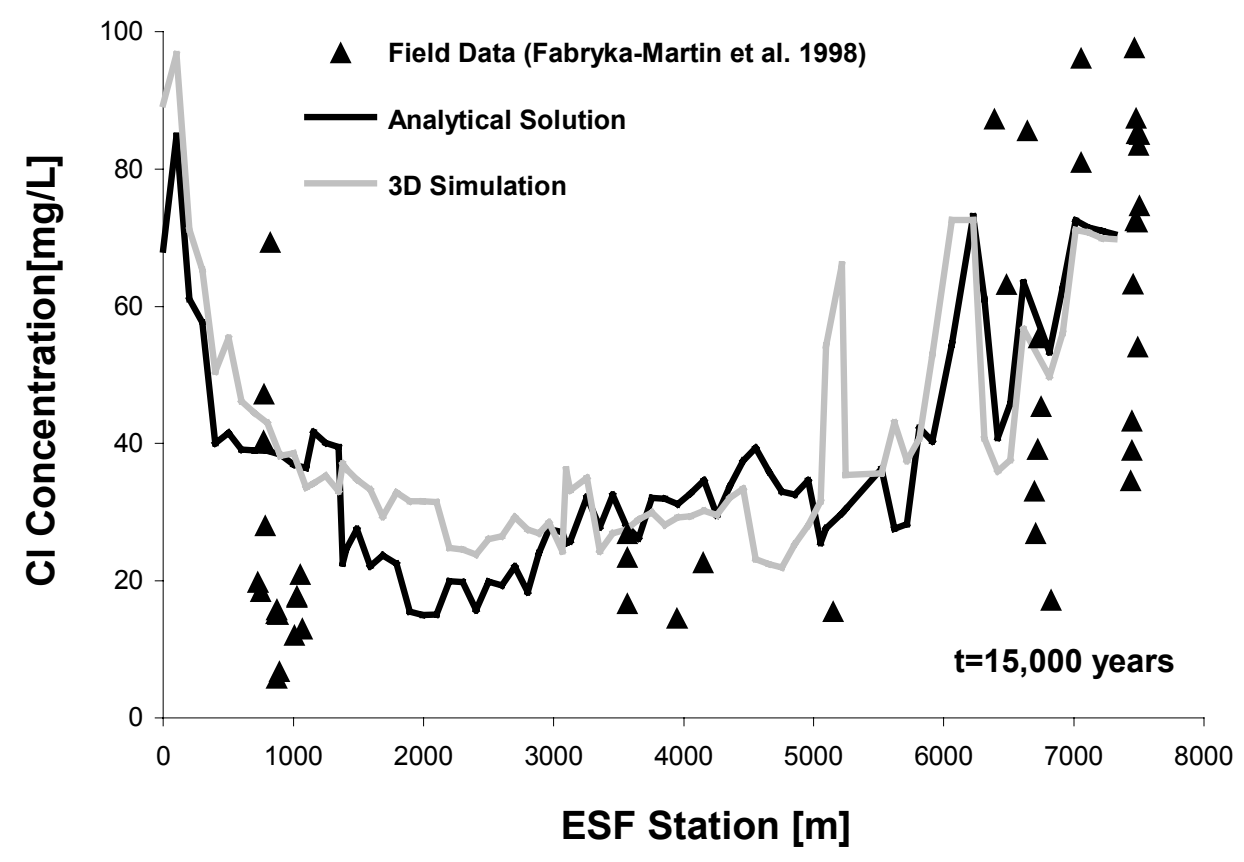

Fig. 15. ESF chloride model results by analytical method and 3-D simulation. 


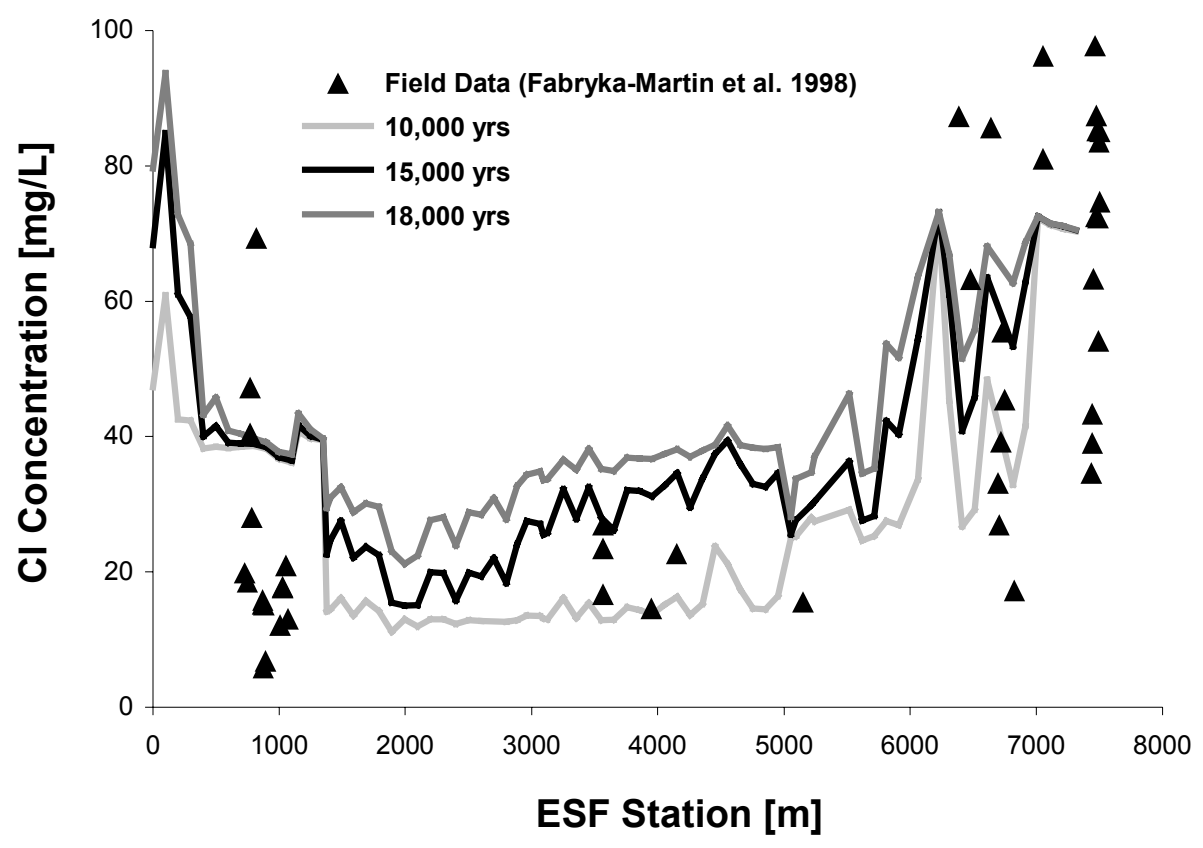

Fig. 16. ESF chloride transient analyses by analytical method.

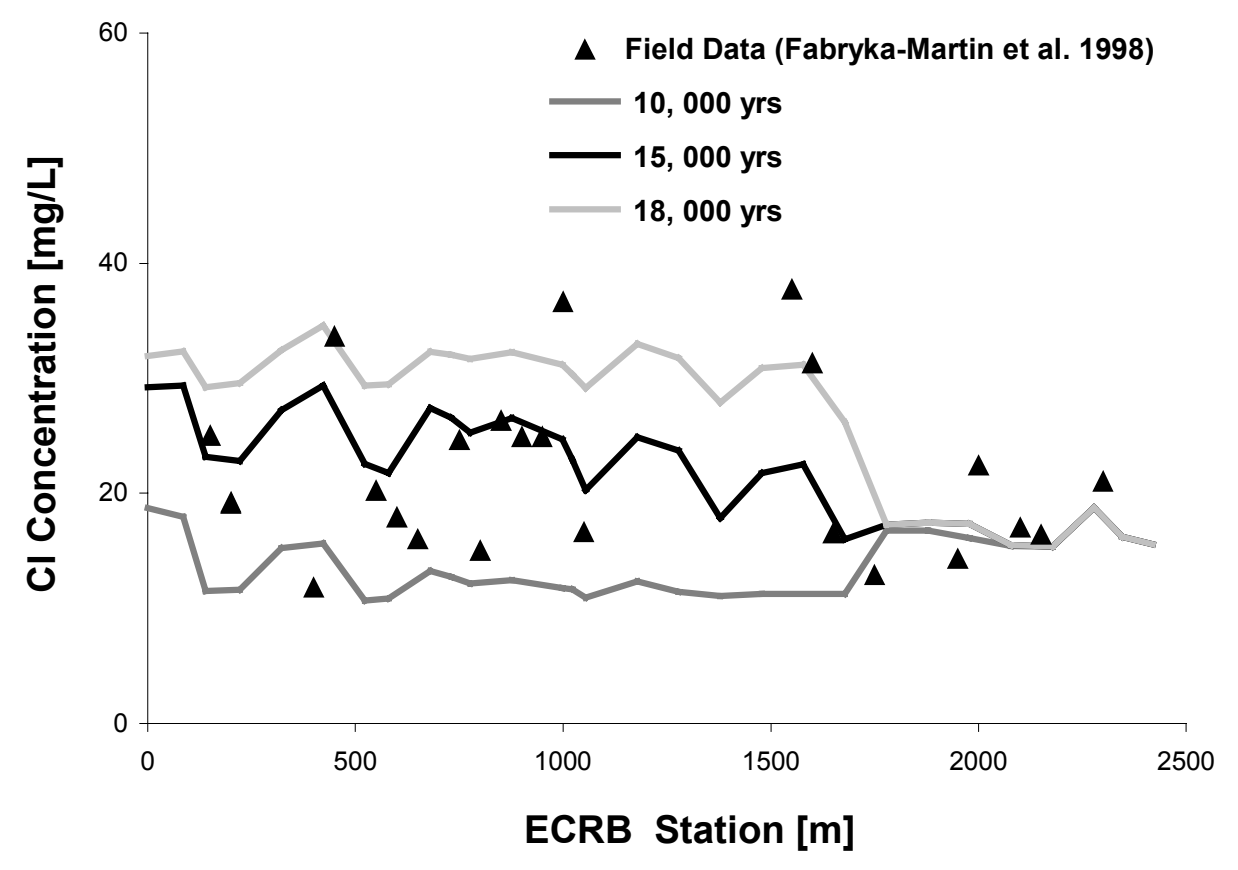

Fig. 17. ECRB chloride transient analyses by analytical method. 


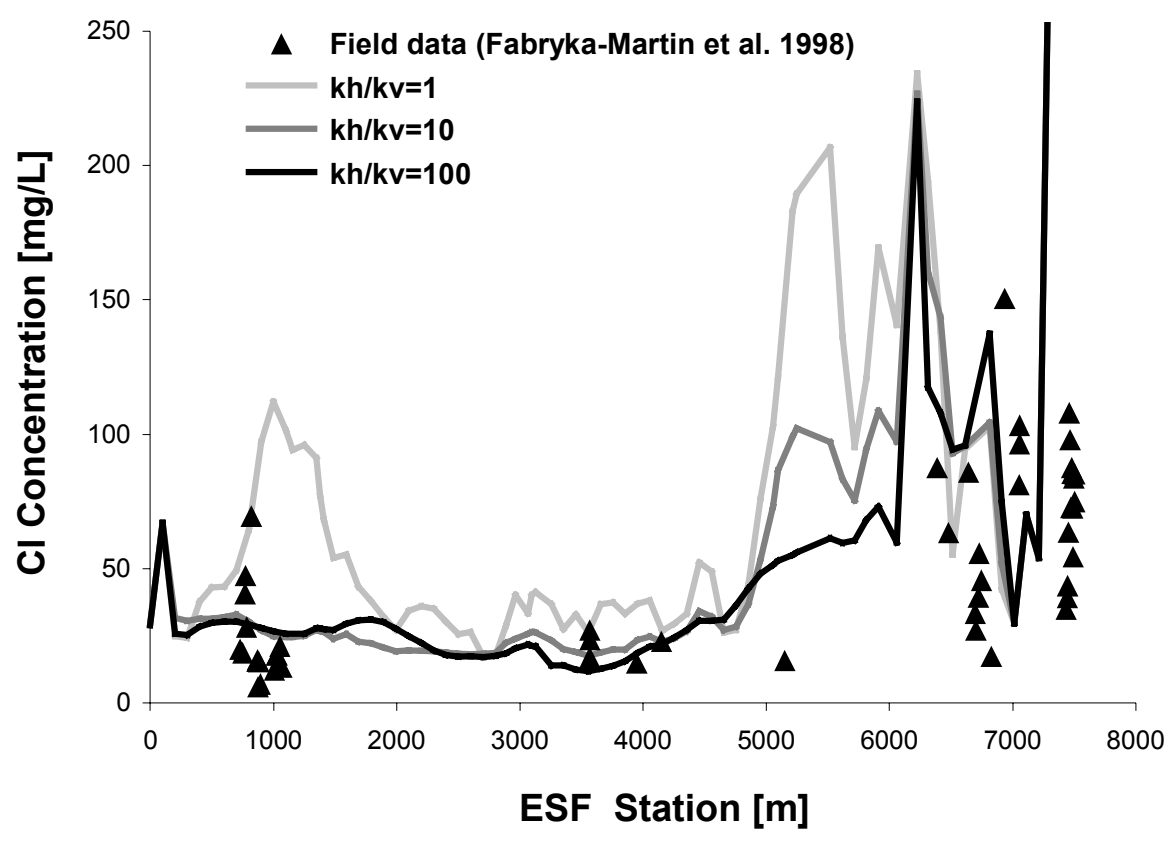

Fig. 18. ESF chloride model results by increased PTn horizontal permeability.

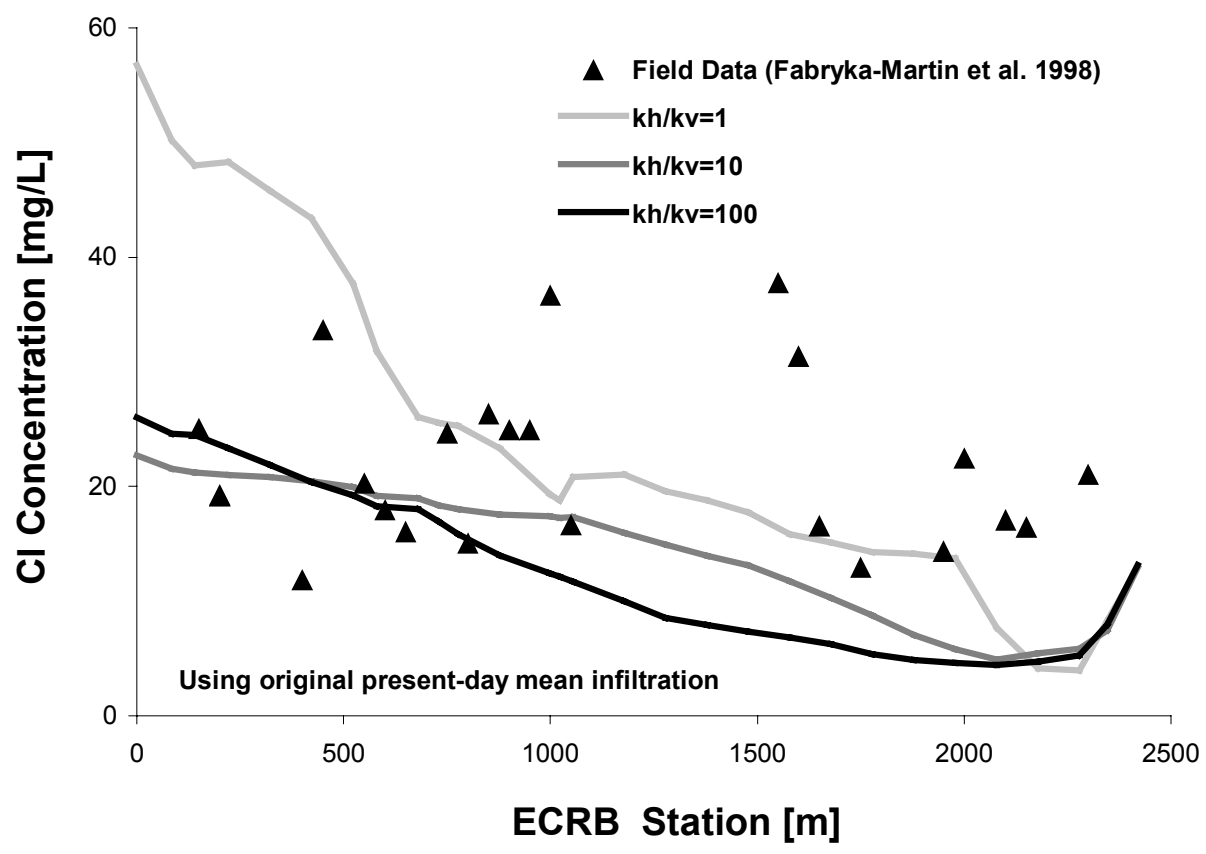

Fig. 19. ECRB chloride model results by increased PTn horizontal permeability. 


\section{UZ\#16}

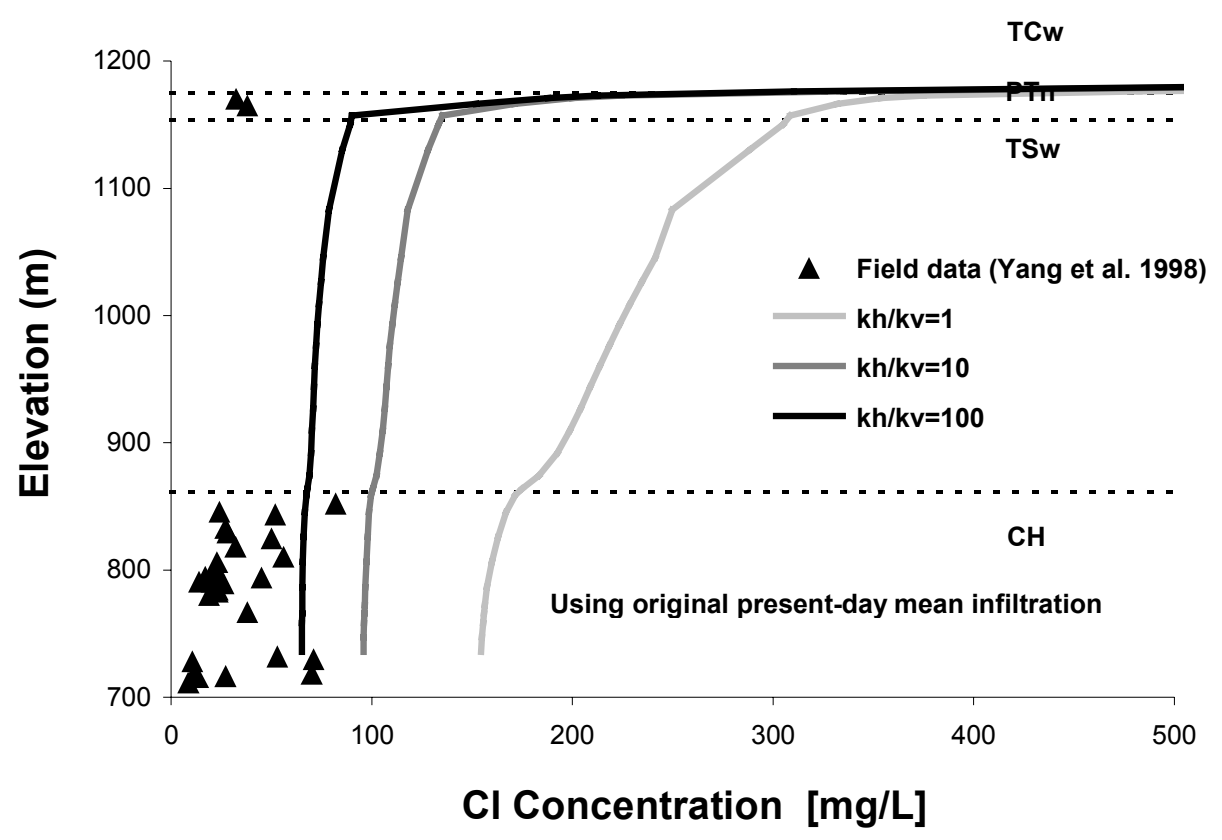

Fig. 20. Borehole UZ\#16 chloride model results by increased PTn horizontal permeability. 


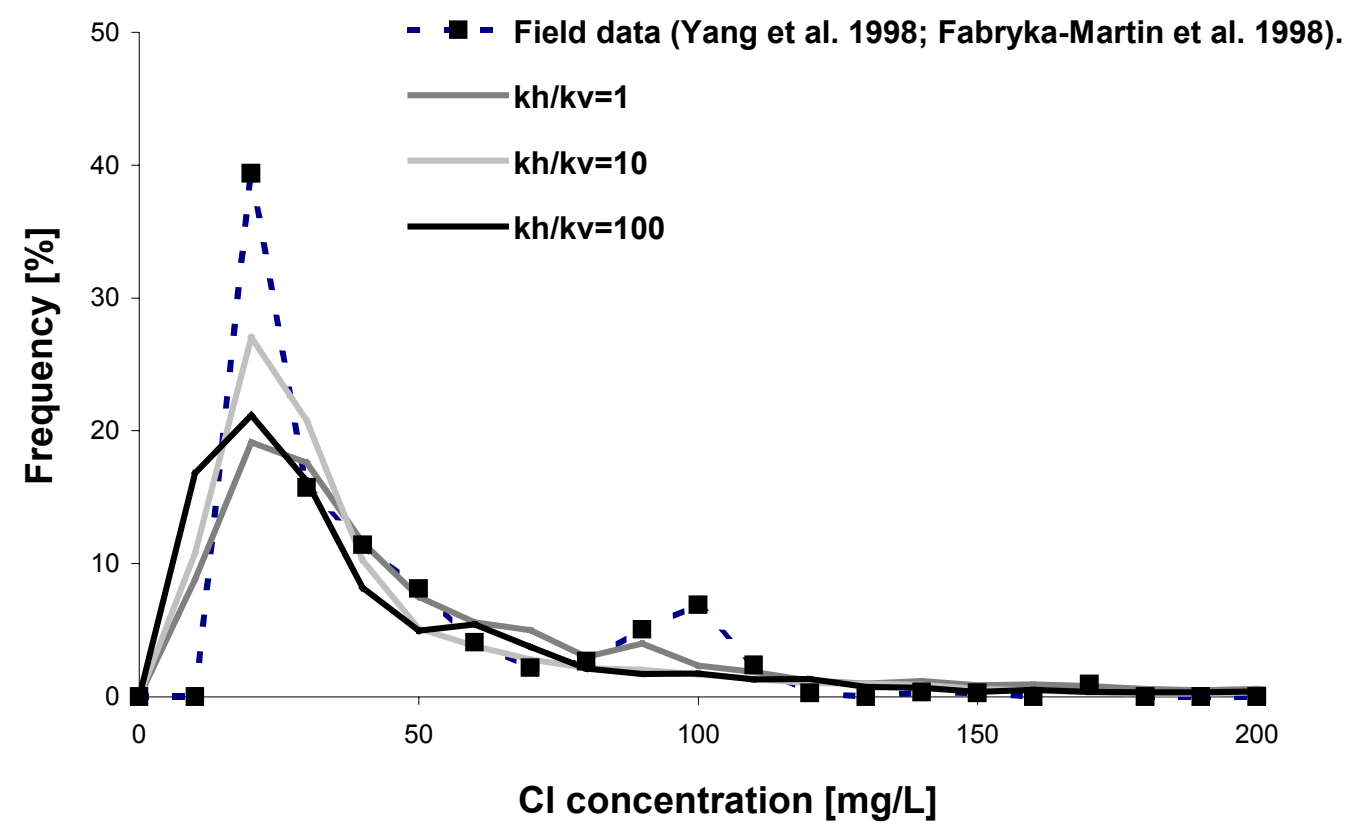

Fig. 21. Frequency of overall chloride distribution in the UZ system with increased PTn horizontal permeability. 